\title{
RIGHT TO A JURY TRIAL IN CIVIL ACTIONS*
}

\author{
FLEMING JAMES, JR. \\ I. The Constitutronal Right to Jury Trul
}

THE federal Constitution guarantees the right to jury trial in civil actions in federal courts, ${ }^{1}$ and nearly every state constitution contains a similar guaranty. While there are some differences among these provisions, they have been given an essentially uniform effect for the purpose under discussion here. They do not extend but preserve the right of jury trial as it existed in English history at some past time, either in 1791 when the seventh amendment was adopted ${ }^{3}$ or, in the case of the states, at the date of the first state constitution. ${ }^{*}$ And at such times not all civil matters were tried to a jury. Issues in actions at law were so tried, with some exceptions; issues in suits in equity were not, unless the chancellor in his discretion sent an issue to a jury for an advisory verdict."

Many new rights and remedies have, of course, been created since the adoption of the federal and state constitutions. In devising new remedies the legislature has considerable latitude to determine whether they shall carry a right to jury trial. ${ }^{6}$ The legislature may even abolish a common law remedy, such as the former action by a servant against his master for injuries caused by the

*This article is from the author's treatise on civil procedure soon to be published by Little, Brown \& Co., Boston, Massachusetts.

iLafayette S. Foster Professor of Law, Yale Law School.

1. U.S. Const. amend. VII.

2. See, e.g., CaL. Const. art. I, § 7; Conn. Const. art. I, § 21. Colorado and Louisianz have no constitutional quaranty of jury trial in civil actions. CoLo. Cosst. art. 2, \$23; Mfiller v. O’Brien, 75 Colo. 117, 233 Pac. 1088 (1924); LA. CoNst. art. 1, § 9.

3. Dimick v. Schiedt, 293 U.S. 474, 476 (1935) ; Baltimore \& C. Line v. Redman, 295 U.S. 654, 657 (1935).

4. See, e.g., People v. One 1941 Chevrolet Coupe, 37 Cal. 2d 283, 287, 231 P.2d 832, 835 (1951) (The constitutional right to jury trial "... is the right as it existed at common law at the time the [State] Constitution was adopted ... and what that right is, is a purcly historical question, a fact which is to be ascertained like any other social, political or legal fact.... It is necessary, therefore, to ascertain what was the rule of the English common law upon this subject in 1850").

Some of the states which were not among the thirteen original colonies interpret their constitutional provisions as preserving the constitutional right as it had existed in the territory when identical to the right secured by the Seventh Amendment to the Federal Constitution, except as it has been modified by later constitutional provision. See, e.g., Whallon v. Bancroft, 4 Minn. 109 (1860) ; St. Paul \& S.C. R.R. v. Gardner, 19 Minn. 132 (1872).

5. Shields y. Thomas, 59 U.S. (18 How.) 253, 262 (1855); Mieriden Sav. Bank v. McCornack, 79 Conn. 260, 64 At1. 338 (1906); Kimball v. Connor, 3 Kan. 410 (1866); Brown v. Heller, 30 N.M. 1, 227 Pac. 594 (1924).

6. See, e.g., NLRB v. Jones \& Laughlin Steel Corp., 301 U.S. 1, $48-49$ (1937) (Congress may provide for administrative finding of unfair labor practice under the Wagner Act, together with administrative determination that reinstatement of discharged employce with award of back pay was proper remedy, without impairing Seventh Amendment). 
latter's negligence, and substitute for it an entirely new system of compensation for all industrial injuries to be administered by a board or conmission which will determine factual disputes without resort to either court or jury. But there are probably limits beyond which a legislature may not go. If a legislature creates a right to be redressed by an action which is analogous to a common law action (e.g., for a penalty such as treble damages, or for compensatory damages caused by wrongful death), it probably may not deprive the parties to the action of a right to jury trial, ${ }^{8}$ unless the new right is given against the sovereign and therefore involves a waiver of sovereign immunity. ${ }^{\circ}$ Where the legislature says nothing about how a new remedy is to be tried, the courts fit it into the nearest historical analogy to determine whether there is a right to jury trial. ${ }^{10}$

One other aspect of the constitutional guaranty of jury trial should be noted. It has been uniformly construed as a right which may be waived by the parties. Statute or court rule may therefore prescribe reasonable conditions for obtaining jury trial, such as timely demand, and may provide that failure to take these steps constitutes a waiver. ${ }^{11}$

7. Mountain Timber Co. v. Washington, 243 U.S. 219 (1917); Cunningham v. Northwestern Improvement Co., 44 Mont. 180, 119 Pac. 554 (1911); State ex rel. Davis-Smith Co. v. Clausen, 65 Wash. 156, 117 Pac. 1101 (1911).

8. See Parsons v. Bedford, 28 U.S. (3 Pet.) 433, 447 (1830). ("By common law, they [framers] meant ... not merely suits, which the common law recognized among its old and settled proceedings, but suits in which legal rights were to be ascertained and determined, in contradistinction to those. .." recognized only in equity or admiralty. "Probably, there were few, if any, states in the Union, in which some new legal remedies, differing from the old common-law forms, were not in use; but in which . . . trial by jury intervened...."

See also Fleitmann v. Welsbach Co., 240 U.S. 27 (1916) ; Meeker v. Lehigh Valley R.R., 162 Fed. 354, 357 (C.C.S.D.N.Y. 1908) (treble damage actions under antitrust laws triable to jury); Olearchick v. American Steel Foundries, 73 F. Supp. 273 (W.D. Pa. 1947) (action for overtime compensation under Fair Labor Standards Act triable to jury); Bellavanco v. Plastic-Craft Novelty Co., 30 F. Supp. 37, 38 (D. Mass. 1939) (The United States patent "... statutes afford two remedies-first, an action on the case to recover damages for infringement of the patent, R. S. $\$ 4919,35$ U.S.C.A. $\$ 67$. Such an action, of course, is one at law and would entitle the parties to a jury trial.") ; Innersprings, Inc. v. Joseph Aronater, Inc., 27 F.R.D. 32, 36 (E.D.N.Y. 1961) (in action for patent infringement ". . . when damages only are sought the action is one at common law within the meaning of the Seventh Amendment.").

See the interesting opinions of Judges Friendly (for the majority) and Clark (dissenting in part), in Damsky v. Zavatt, 289 F.2d 46 (2d Cir. 1961).

9. See, e.g., the Federal Tort Claims Act, 18 U.S.C. $§ 2674$ (1958); N.Y. Court of Claims Act both of which provide for determination of fact issues without a jury. Cf. Auffmordt v. Hedden, 137 U.S. 310 (1890).

10. Luria v. United States, 231 U.S. 9 (1913) (statutory suit to cancel naturalization certificate for fraud not triable to jury); Strelitz v. Surrey Classics, Inc., 7 F.R.D. 101 (S.D.N.Y. 1946) (proceeding to compel reemployment of discharged soldier not triable to jury); 5 Moore, Federat Practice $\{38.11$ [7] (2d ed. 1951).

11. Some constitutions expressly provide for waiver. See, e.g., the California provisions cited supra note 2 . Others, like the Seventh Amendment and the Connecticut constitutional provision (stipra note 2) do not. Under either type, there seems to be no doubt 
The federal courts and most state courts hold that there is no constitutional barrier to legislative or judicial extension of jury trial to issues which were formerly equitable. ${ }^{12}$ A few state constitutions provide for an extension of jury trial beyond those issues allotted to a jury by history; ${ }^{13}$ few others have construed their constitutions as guaranteeing the right of non-jury trial of equitable issues. 14

\section{A. The Historical Test}

Thus, most constitutions preserve the right to jury trial upon what may be called a historical test. ${ }^{15}$ The question then arises whether this freezes the right absoultely as it was in England in 1791 (for example), or whether it has some elasticity so as to accommodate extensions or contractions of jury trial and, if so, what the limits of this elasticity may be. Some aspects of this question have probably not had the attention they deserve and have not received clear

about the constitutionality of providing for waiver of jury trial unless unrcasonable conditions are placed upon obtaining it. Bennett v. Hillman, 37 Cal. App. 586, 174 Pac. 362 (1918); McKay v. Fair Haven \& W. R.R., 75 Conn. 608, 54 Atl. 923 (1903) ; James, Trial by Jury and the New Federal Rules of Procedure, 45 YaLE L.J. 1022, 1024-25 (1936). The Supreme Court probably believed that reasonable conditions can constitutionally be put upon obtaining a jury since rule 38 of the Federal Rules of Civil Procedure, promulgated by the Court, provides for jury waiver unless a party makes a timely affirmative jury claim; ef. Capital Traction Co. v. Hof, 174 U.S. 1 (1899).

For a case holding specific conditions to be unreasonable, see $L_{3}$ Bowe v. Balthzzor, 180 Wis. 419, 193 N.W. 244 (1923) (\$24 fee in municipal court with civil jurisdiction not to exceed $\$ 1,000)$.

12. See Beacon Theatres v. Westover, 359 U.S. 500,510 (1959); Thermo-Stitch, Inc v. Chemi-Cord Proc. Co., 294 F.2d 486, 490 (5th Cir. 1961); Hurwitz v. Hurvitz, 136 F.2d 796, 798-99 (D.C. Cir. 1943). For state cases, see, e.g., Phillips v. Gorham, 17 N.Y. 270 (1858) ; Ely v. Early, 94 N.C. 1 (1886); Van Hecke, Trial by Jury in Equity Cases, 31 N.C. L. REv. 157 (1953) ; Note, The Right to a Nonjury Trial, 74 HARv. L. REv. 1176, 1179 (1961).

13. TeXAs Const. art. $5, \S 10$. North Carolina has so interpreted her constitutional provision. Lee v. Pearce, 68 N.C. 76 (1873). There were decisions in Arizonz, Mfassachusetts, and New Hampshire, all now overruled, which so construed the constitutional provisions in those states. Georgia and Tennessee have statutes of long standing which provide for jury trial of issues of fact in equity cases. Other states have also experimented with this practice only to abandon it. The whole subject is admirably set forth in Van Heele, Trial by Jury in Equity Cases, 31 N.C. L. Rev. 157 (1953).

14. Brown v. Buck, 75 Mich. 274, 42 N.W. 827 (1889); State v. Nieuwenhuis, 49 S.D. 181, 207 N.W. 77 (1926) ; Callanan v. Judd, 23 Wis. 343 (1863); Van Hecke, Trial by Jury in Equity Cases, 31 N.C. L. REv. 157, 164, 166, 167, 171 (1953) (stating that there were seven such states and one federal circuit); Note, The Right to a Nonjury Trial, 74 Harv. L. REv. 1176 (1961).

15. The seventh amendment provides that "the right of trial by jury shall be preserved. ..." In the states which have them "... the constitutional guarantees of jury trial in civil cases usually are phrased in strong but not very detailed language. The constitutional authors generally were content to provide that trial by jury 'shall remain inviolate forever', 'shall remain inviolate', 'shall be secured', 'shall remain as heretofore', etc. . . . At least implicitly the purport is that the right shall remain in substance as it was when the state constitutional provision was adopted." Louisell axd Hazard, Cases axd Miatertals on Plending and PROCEDURE 938 (1962). See also cases cited sipra, notes 3 and 4. 
answers in judicial decisions. The following considerations should be noted as bearing on the problem.

The doubts run in both directions. It is true that most constitutions do not forbid legislative or perhaps judicial extension of jury trial right boyond the constitutional right. ${ }^{16}$ But the question here is a different one: whether the constitution should be so interpreted as to extend the constitutional right itself beyond the strict historical pattern.

Before the adoption of the constitutions the line between law and equity (and therefore between jury and non-jury trial) was not a fixed and static one. There was a continual process of borrowing by one jurisdiction from the other; there were less frequent instances of a sloughing off of older functions. An instance of the latter may be seen from early petitions asking the Chancellor to grant ordinary legal remedies because of the corruption or political impotence of the regular courts, a branch of equity jurisdiction that withered and died in the fifteenth century.17

. In the course of time many matters and issues worked over into law from equity. The growth of general assumpsit, "especially that implied contract, so highly beneficial and useful, of having undertaken to account for money received to another's use," had already become in Blackstone's time a legal action "almost as universally remedial as a bill in equity." 18 Many matters such as duress, fraud, illegality, and perhaps even payment of a specialty, which had once been cognizable only in equity, ${ }^{10}$ were familiar defenses to a legal action by the end of the eighteenth century.

On the other hand, chancellors came to try an ever-growing number of issues which once they had left to be tried at law. There was a time, for instance, when equity was reluctant to grant specific performance where the existence of the contract was disputed; the parties, it was thought, should settle such disputes at law..$^{20}$ Later equity courts had no hesitation about deciding for themselves whether there was a contract. ${ }^{21}$ Again the notion developed that if a ground for equitable relief existed, equity would not stop with the

\section{Supra note 13.}

17. 1 Holdsworth, A History of English Law 405, 406 (7th ed. 1956); Maithand, EQuity 5, 6 (2d ed. 1936); WaLSH, EquitY Ch. 2 (1930).

18. 3 Biackstone, Commentaries 432 (hereinafter cited as Blackstone). Holdsworth thought that Blackstone exaggerated the extent to which law and equity had drawn together. Holdsworth, Blackstone's Treatment of Equity, 43 HARv. L. REv. 1 (1929). But nothing in Foldsworth's comments impairs Blackstone's authority for propositions in the text.

19. See exposition in Cook, Equitable Defenses, 32 YaLE L.J. 645 (1923) ; cf. Hinton, Equitable Defenses under Modern Codes, 18 Mrch. L. Rev. 717 (1920).

20. Huddleston v. Briscoe, 11 Ves. Jr. 583, 32 Eng. Rep. 1215 (Ch. 1805) ; cf. Colson v. Thompson, 15 U.S. (2 Wheat.) 336 (1817) ; Waters v. Howard, 1 Md. Ch. 112 (1847).

21. Altoona Elec. Eng'r \& Supply Co. v. Kittaning \& F. C. St. Ry. Co., 126 Fed. 559 (W.D. Pa. 1903) ; Canister Co. v. Leahy, 182 F.2d 510 (3d Cir. 1950) ; Rash v. People's Deposit Bank \& T. Co., 192 F.2d 470 (6th Cir. 1951) ; Fraser v. Geist, 1 F.R.D. 267 (E.D. Pa. 1940); Mahon v. Bennett, 81 F. Supp. 901 (W.D. Mo. 1948). 
granting of equitable relief but would (at least if plaintiff wished) 22 decide all aspects of the controversy, and this would often include issues which were ordinarily for the law courts. ${ }^{23}$ Thus, if a plaintiff sought reformation of a contract for mutual mistake, the chancellor, if he found mutual mistake, would not only reform the contract but also try any remaining issues which would determine whether damages should be awarded for breach of the contract as reformed, and decree payment of the proper amount.24 Ordinarily, where the ground for equitable relief failed, the bill would be dismissed and the parties left to seek in the common law courts whatever legal remedies remained.5 But in 1786 an equity court decided not to dismiss the bill but to retain jurisdiction for the granting of legal relief where the ground for equitable relief (specific performance) failed only because of defendant's wrongful conduct after the suit was begun. ${ }^{28}$ This granting of substituted legal relief in equity enjoyed a limited expansion after that ${ }^{27}$

The borrowing by each jurisdiction from the other was not accompanied by an equivalent sloughing off of functions. ${ }^{28}$ This led to a very large overlap between law and equity. Many facts-fraud in the inducement, for instance-

22. That it was at plaintiff's option, seems clear from Whitchurch v. Golding, 2 P. Wms. 541, 24 Eng. Rep. 852 (Ch. 1729) ; Dormer v. Fortescue, 3 Atks 124, 26 Eng. Rep. 875 (Ch. 1744); 1 StoRy, Equity JuRISPRUdeñCe $\S \S 71,82,83$ (14th ed. 1918).

23. Parker v. Dee, 2 Ch. Cas. 200, 22 Eng. Rep. 910 (Ch. 1674); Middletown Bank v. Russ, 3 Conn. 135 (1819); Rathbone v. Warren, 10 N.Y. 587 (1813); sources cited supra note 22.

24. 1 Story, Equity Jurisprudence \& 161 (14th ed. 1918); Imperial Shale Brick Co. v. Jewett, 169 N.Y. 143, 62 N.E. 167 (1901).

25. Dowell v. Mitchell, 105 U.S. 430 (1881) ; Linden Inv. Co. v. Honslain Bros. Co, 221 Fed. 178 (8th Cir. 1915); 1 Podreroy, Equity Jurisprudexce $§ \S 237$, 237 (5th ed. 1941).

26. Denton v. Stewart, 1 Cox Ch. 258, 29 Eng. Rep. 1156 (Ch. 1786). See also Todd v. Gee, 17 Ves. Jr. 273, 34 Eng. Rep. 106 (Ch. 1810) ; Mfilkman v. Ordway, 106 Mrass. 232, 255 (1870).

27. Gulbenkian v. Gulbenkian, 147 F.2d 173 (2d Cir. 1945); Saperstein v. Mfechanics \& Farmers' Sav. Bank, 228 N.Y. 257, 261, 126 N.E. 708, 709 (1920); McLennan v. Church, 163 Wis. 411, 158 N.W. 73 (1916) ; Levin, Equitable Clean-Up and the Jury: A Suggested Orientation, 100 U. PA. L. Rev. 320 (1951); 1 Podreroy, EQuity Jurrsprudexce § 237 (5th ed. 1941).

28. Eyre v. Everett, 2 Russ. 381, 382, 38 Eng. Rep. 379 (Ch. 1826) ("[T]his court will not allow itself to be ousted of any part of its original jurisdiction, because a court of law happens to fall in love with the same or a similar jurisdiction...."); Sweeny v. Williams, 36 N.J. Eq. 627, 629 (1883). ("When courts of law have of their own notion extended their jurisdiction over cases theretofore solely cognizable in equity, the jurisdiction of the latter courts has been in no respect abridged, although when the jurisdiction at law has become well established, the equity jurisdiction has in some cases declined."; 1 Posreror, EquTTY JuRISPRUdence $\$ \S 276-281$ a (5th ed. 1941). Pomeroy concludes: "The enlargement of the jurisdiction at law, by the ordinary process of legal development, has not, in general, affected the pre-existing jurisdiction of equity." Id. at 618.

See also Kemp v. Pryor, 7 Ves. Jr. 237, 249, 32 Eng. Rep. 96, 101 (Ch. 1802) ; Toulmin v. Price, 5 Ves. Jr. 235, 238-39, 31 Eng. Rep. 563, 565 (Ch. 1800); Viele v. Hosg, 24 Vt. 46 (1851). 
might have been presented and decided either at law or in equity, depending on the context in which they arose. ${ }^{29}$ It also meant that the rubric which precluded equitable relief when the remedy at law was adequate ceased to have any claim to universal or even general validity, although it continued to be applied in some situations. Blackstone noted that every bill in equity suggested the inadequacy of legal remedy, but continued: "But he who should from thence conclude that no case is judged of in equity where there might have been relief at law, and at the same time casts his eye on the extent and variety of the cases in our equity reports, must think the law a dead letter indeed." "Bo

This process of borrowing continued in American jurisdictions, to some extent at least, even after the constitutions were adopted. The issue of fraud in the inducement as a defense to an action on a specialty worked over into law during the nineteenth century. ${ }^{81}$ During the same century courts of equity came to try disputed issues of contract vel non (in specific performance), va nuisance vel non (in suits to enjoin nuisances), ${ }^{88}$ and even, in some states, title vel non (in suits to enjoin trespasses). ${ }^{34}$ The notion of substituted legal relief in equity enjoyed, as we have seen, ${ }^{35}$ a limited extension during the nineteenth century. For the most part these steps were taken without any indication that the courts were aware of the constitutional problems which the steps involved. But the New York Court of Appeals faced the question squarely when in 1937 the constitutionality of an 1830 statute was challenged.80 The statute gave equity courts the power to enter deficiency decrees in mortgage foreclosure actions, ${ }^{37}$ a freedom which probably had been denied them before the statute. The majority of the court upheld the statute, noting that when equity properly took jurisdiction of a matter it generally decided all issues presented. Since the equity jurisdiction over foreclosures was clear, the former New York law requiring a second suit to get a deficiency decree was a deviation from general equity principles which might be corrected by the legisli-

29. For description of the various remedies for fraud see Prosser, Torts 520-22 (2d ed. 1955); Shuldan \& James, Cases and Materiazs on Torts 824-27 (2d ed. 1952). The legal remedies included the action on the case for fraud and an action for the considerttion parted with (general assumpsit, etc.) after rescission at law. The equitable remedies include a suit for rescission and the constructive trust device.

30. 3 BiACKSTONE 434 .

31. Enelow v. New York Life Ins. Co., 293 U.S. 379 (1935) ; Prudential Life Ins. Co. v. Saxe, 134 F.2d 16 (D.C. Cir.), cert. den. 319 U.S. 745 (1943).

The history of the matter is traced in Abbot, Frand as a Defence at Late in the Federal Courts, 15 CoLum. L. Rev. 489 (1915).

32. See supra note 21.

33. Lewis, Injunctions against Nuisances and the Rule Requiring the Plainiff to Establish his Right at Law, 56, U. PA. L. REv. 289 (1908); Note, Trial by Jury in Stits to Enjoin Nuisances, 25 CoLUar. L. REv. 641 (1925).

34. See Comment, 32 YaLE L.J. 707, 709-10 (1923); cf. Lewis, supra note 33.

35. See note 27 supra.

36. This statute is dealt with and held constitutional in Jamaica Sav. Bank v, M. S. Investing Co., 274 N.Y. 215, 8 N.E.2d 493 (1937).

37. Ibid. 
ture. The statute was enacted after the constitutional provision for a jury trial was adopted, ${ }^{38}$ but before the union of law and equity was completed. The decision upholds a change in the strict historical position of jury trial and therefore sanctions a construction of the constitution which will accommodate such changes when they follow authentic historical patterns for change. The reason for the change (avoidance of two suits) is one which no longer exists under the Code. But it is submitted that the decision should justify a similar change made today for reasons which have continuing vitality.

At no time in history was the line dividing equity from law altogether-or even largely-the product of a rational choice between issues which were better suited to court or to jury trial. There is little to suggest that the chancellor's initial choice of a procedure borrowed from canon law reflected a considered rejection of jury trial. ${ }^{30}$ Rather, the choice between law and equity frequently was made upon considerations of other factors. For when equity procedure took shape it differed from the procedure at law in several important respects. Evidence in equity was produced largely by sworn pleadings and written depositions taken upon written interrogatories, ${ }^{40}$ rather than

38. "The trial by jury in all cases in which it has been heretofore used shall remain inviolate forever." N.Y. CoNST. art. 1, § 2. These words have "been part of the fundamental law of the state since the adoption of the Constitution of 1821," Loughran, J., dissenting in Jamaica Sav. Bank v. M. S. Investing Co., 274 N.Y. 215, 224, 8 N.E.2d 493, 496 (1937). The majority took no issue with this statement.

39. Thus there is no mention of a desire or choice to reject jury trial in the standard accounts of the origins of equity. See, e.g., 3 BLACKsTone 50-53, 434-55 (pointing to fact that many early chancellors were churchmen); 1 STORY, EQUTrY JURSPRUDENCE, ch. 2 (14th ed. 1918) ; Kerty, AN Historical Sketch of the Equitable Jurisdiction of tre Count of Chancery 81 (1890) (case in 1374 shows the subpoena and the examination of defendant already in regular use by Council "having been borrowed perhaps by the Chancellors and other Canonists who sat in it from the procedure of the Courts Christian where both had long been established."), \& ch. 5 (cases on common law side of chancery referred to jury, but cases on equity side so referred only exceptionally). See generally, 1 Horosworte, History of ENGLish Law ch. 5 (7th ed. 1956); MLATrLand, Equity 5 (2d ed. 1936) ; Pidcrenett, A Concise History of the Coararow Law 163-65, 178-81, 675-84 (5th ed. 1956); 1 Poareroy, EQuity Jurisprudence $\S \S 30-37$ (5th ed. 1941); Walsu, A TREATISE ON EQUTTY ch. 2 (1930).

A recent author has, indeed, suggested that the early chancellors may have chosen nonjury trial because much of their work was "unsuitable for resolution by the typically illiterate jury." Note, The Right to a Nonjury Trial, 74 HARv. I. REv. 1176, 1181 (1961). There is, however, no citation of authority for the statement and while the suggestion seems plausible it apparently rests on speculation.

40. The equity procedure in the 18th century is described in 3 BLAczstone 442-55. For an account of the taking of evidence in an earlier case, see KerLY, op. cit. supra note 39, at 68-69. In Chapter 8 of the same work, Kerly describes in some detail the taking of evidence during the period from Wolsey to the Commonwealth which, he says, was the practice that in the main lasted down to the Chancery reforms of the 19th century.

In New York, the old method was to have testimony in equity cases taken before masters and examiners in Chancery, a practice which proved cumbersome and expensive in practice. The Constitution of 1846 , which paved the way for the Field Code, contained a provision that: "The testimony in equity cases shall be taken in like manner as in cases at law." Art. VI, \& 10. See New York, Report of the Debates and Proceedings of tise Cos- 
by testimony taken orally and subject to oral cross-examination, all in the presence of the trier of fact. At law the parties to an action were neither competent nor compellable to testify, ${ }^{41}$ whereas in equity each party could offer his own sworn statements and also "probe the conscience" of his adversary by propounding written interrogatories, which had to be answered under oath. ${ }^{42}$ The chancellor used specific remedies which were not available to the law courts, and the chancellor could handle multiple parties and the possibility of multiple suits in a way that the law courts had not developed.10 The procedure of each tribunal had to be taken as a package, and each procedure had substantial limitations which the other did not share. In equity the procedure was epistolary, included the statements of both parties, might provide for specific relief and handle multiple parties and suits, and involved no jury. At law the procedure involved oral testimony and cross-examination at a jury trial, relief in rem, and the unavailability of the testimony of either party.

From the above it may be seen that even where the allocation of issues between the jurisdictions was based on rational considerations, it would often be dictated by some factor other than jury trial. When the chancellor was faced with a prickly question of credibility of witnesses, his rational desire for the benefits of demeanor evidence could be satisfied only by sending the issue to the law court with its jury. Where an accounting between business associates was sought, if the inquiry was to have the benefit of the testimony of the parties (the two witnesses who could shed the most-sometimes the onlylight on the matter), it would have to be conducted in equity, where the chancellor would decide questions of fact without a jury. The same thing was true where specific performance of a contract was appropriate rather than damages for its breach, or when unnecessary multiplicity of suits was to be prevented. To put it colloquially, jury trial (or court trial) was often merely the tail of the dog under a system where you had to take the whole dog.

The extensions of equity jurisdiction noted above ${ }^{44}$ were also motivated in part by considerations having little or nothing to do with the merits or flaws

Strtutional Convention of 1846 782-85. This is probably true today in all American jurisdictions.

41. 2 WiGMroRe, EVIDENCE §§ 575-77 (3d ed. 1940).

42. 3 Brackstone 442-51. The bill and answer might be supplemented by affidavits. The bill itself contained not only statements of fact but interrogatories propounded to defendant. 1 PoMeroy, EQUiTY JuRisdiction $\$ 191$ (5th ed. 1941). "The first answer was ... rarely deemed sufficient, and second, third, fourth and further answers might be ordered on the Master's Certificate, the defendant paying ... costs as ordered. .." KERLY, op. cit. suppra note 39 , at 120 .

43. 1 Poneroy, Equity Jurisdiction §§ 37, 103-17, 243-75 (5th ed. 1941).

44. Text at notes 21-27 supra.

43. Levin, Equitable Clean-up and the Jury: A Suggested Orientation, 100 U. PA. L. REv. 320 (1951).

44. These struggles are recounted in the sources cited sipra note 39. Sec, c.g., Kenux, op. cit. supra note 39 , chs. $4,7,10 ; 1$ HoLDSWORTH, op. cit. supra note 39 , at 459-65; WALs1, op. cit. supra note $39, \S \S 5,6$. 
of jury trial. They reflected rather the concern of equity to mitigate the hardships of the dual system. ${ }^{45}$ An equity suitor who was relegated to his legal remedy would always face the expense and delay of starting all over again; and he might also risk loss of his legal rights through the running of a statute of limitations or inability to obtain jurisdiction over a defendant.

In addition to these considerations, it is familiar learning that the allocation of a dispute to either law or equity was often made on the basis of considerations relevant to the long political struggle between the King and Parliament in England. These considerations had little to do with the efficient administration of justice. ${ }^{46}$ And while the jury occasionally became a symbol and a bone of contention in this struggle, ${ }^{ \pm 7}$ yet here, too, many factors other than the mode of trial often dominated the allocation of subject matter.

It would be a mistake, of course, to suppose that chancellors were never concerned with the jury trial problem in taking or refusing jurisdiction. One reason often given for assuming equitable jurisdiction over an accounting was the difficulty of the case for a jury. ${ }^{48}$ The issue of mutual mistake in written instruments may well have been kept from juries out of fear that they might be too ready to upset, on uncritical emotional grounds, the stability which written instruments ought to represent. ${ }^{49}$ On the other hand, when equity courts refused to try disputed questions of legal title in suits to enjoin trespasses, the appropriateness of trying such a dispute to a jury was often stressed. ${ }^{50}$

\section{B. Modern Application of the Historical Test}

Under a merged procedure, few if any of the differences between law and equity continue to have any vitality, except the question of mode of trial. No longer must an entire set of procedural incidents be taken as a package, either legal or equitable. A single court is charged with applying the whole law of

45. Thus in Heath v. Rydley, Cro. Jac. 335, 79 Eng. Rep. 286 (K. B. 1614), the court reasoned that after a common law judgment "the party ought to be quict, and to submit thereto. . " rather than resort to Chancery, "for neither writ of error nor attaint can be brought to reverse the decrees [of chancery] ; otherwise it is upon trials at the common law; for all matters are there decided either by a jury of twelve men, against whom (if they err in their verdict) an attaint lieth; or by the Judges, where if they err in their judgment, the party aggrieved may bring his writ of error." The notion scems to be that the chancellor should not use his extraordinary power to interfere with a composite, appealable judgment representing to some extent the popular and parliamentary side.

The decision was put on statutory ground. See 27 Edw. III, c. 1 (1353) and Prohibition, $4 \mathrm{Hen}$. IV, c. 23 (1402) but the court sought to justify its reading of the statutes by the reasoning described above.

48. See, e.g., Ludlow v. Simond, 2 Cai. R. 1, $51-53$ (N.Y. Ch. 1804); Bennett v. United Lumber \& Supply Co., 110 Conn. 536, 538, 148 A. 369 (1930); cf. Stosx, Equity JURISPRUDENCE 425 (14th ed. 1918).

49. McCormick, The Parol Evidence Rule as a Procedural Device for Control of the Jury, 41 Y ALE L.J. 365 (1932); 9 WIGMORE, EvIDENCE $\$ 2426$, at 86 (3d ed. 1940).

50. Freer v. Davis, 52 W. Va. 1, 43 S.E. 164 (1902). Cf. Attorney General v. Cleaver, 18 Ves. 211, 217-18, 34 Eng. Rep. 297, 299 (Ch. 1811) ; New Castle v. Raney, 130 P2. 546, 562 (1890) (both nuisance cases). 
the land and drawing from it whatever is appropriate to any civil action. All trials are conducted by oral examination of available witnesses in court. Parties are competent and compellable to testify upon any issue. There is no reason, apart from history, why sharply disputed issues of fact in an action seeking specific performance of a contract should not be tried to a jury if that mode of trial is thought preferable. And no other reason to keep a court from assigning a complicated building contract case for court trial if the isstes are deemed to be beyond the competence of the jury.

The considerations discussed above tend to show that the historical test of jury trial right embodied in our constitutions is probably not well-adapted to the merged or united procedures of the present day. It carries too much of the deadwood of the past. A critical use of history may be an excellent guide to present problems, but a critical use takes account of changes in conditions as well as similarities. The historical constitutional test is with us, however, and probably will remain so, because men are unlikely to agree on any basic changes. If that is so, then the above considerations argue in favor of an elastic construction of the historical test by the courts in order to accommodate further shifts of the kind and along the lines of those which were continually taking place in the very period of history to which the constitutions refer. And if such shifts are to be countenanced at all, the courts shotld judge them on the basis of considerations which have vitality in terms of modern judicial administration and not in terms which had relevance only under the divided procedure.

The arguments for a static historical test are (1) its greater protection of the jury trial right from inroads by active courts which would restrict the right; (2) the curb it would put upon equally active courts bent on enlarging the scope of jury trials; and (3) its greater certainty. Since the value of jury trial in civil cases today is a hotly disputed issue and since both the constitutions and the codes embody a judgment that it should be neither expanded (by any general procedural system) nor contracted at all, much can be said for a static historical test.

It is submitted, nevertheless, that there should be some room for change from a pattern made nearly two centuries ago and that the arguments against excesses can be substantially met by confining the changes within the carefully circumscribed limits charted by the New York Court of Appeals.

\section{The Jury Trial Problems Inherent in a United or Merged Procedure}

\section{A. The Choice of Mode of Trial at Common Law}

The jury trial problem as we know it today is a product of the united procedure; it had no counterpart under the old system. To be sure, some problems concerning jury trial were presented even before merger. We have seen how the chancellor would sometimes decline to take jurisdiction for fear of trespassing on the right to a jury, ${ }^{\text {b1 }}$ and how he would at other times take jurisdic-

51. See note $\mathbf{5 0}$ supra. 
tion because of the unsuitability of jury trial..$^{52}$ But once it was conceded or determined that a case was in the proper court, the mode of trial to be had followed nearly automatically. For trial of the issues made by the pleading, a jury was all a law court had to offer. Except for a discretionary advisory jury, court trial was all that equity would afford. This simplicity was purchased, however, at the price of much hardship and waste by way of double actions to get complete relief and frequent dismissals of meritorious claims brought to the wrong forum.

Any true merger of law and equity avoids these hardships of the old system. To do so it provides that all relief, legal and equitable, may be sought in a single action $;^{53}$ moreover, it must be sought in a single action where it arises out of a single transaction or occurrence. Thus many a civil action of today comprises more than any action could before the merger. When this aspect of merger is coupled with a constitutional guaranty of jury trial geared to the old system, and a decision not to extend the scope of jury trial, complex problems arise.

\section{B. The Provisions for Mode of Trial in Merged Systents}

To meet the jury trial problem the original New York Code contains a provision which was widely copied in other early codes. It read thus:

Whenever, in an action for the recovery of money only, or of specific real or personal property, there shall be an issue of fact, it must be tried by a jury, unless a jury trial be waived, as provided in section 221, or a reference be ordered, as provided in sections 225 and 226.50

Another section of this Code, also widely copied, provided for waiver of jury trial by written consent of the parties filed with the the clerk, by oral consent in open court entered in the minutes, or by failure to appear at the trial. ${ }^{.0}$

52. See notes $48-49$ supra.

53. This was the comerstone of the original New York Code. See NEw Yorn, Frnst Report of the Comasissioners on Practice and Pleadings 67-88 (1848) (hereinafter cited as First REPORT of CouronISSIONERS).

Accordingly, N.Y. Sess. Laws (1848), ch. 379, $§ 62$ abolished "[ $t]$ he distinction between actions at law and suits in equity, and the forms of all such actions and suits," and provided for "but one form of action, for the enforcement or protection of private rights and the redress or prevention of private wrongs, which shall be denominated a civil action." See N.Y. CIV. PRAC. ACT \& 8 (1920); N.Y. Crv. PrAC. L. R. § 103 (a) (1962, eff. Sept. 1, 1963). See Clark, Code Pleading $\$ 15$ (2d ed. 1947).

This objective is implemented under the federal rules by Fed. R. CIv. P. 2, 8(c) (2).

54. Hennepin Paper Co. v. Fort Wayne Corrugated Paper Co., 153 F.2d 822 (7th Cir. 1946) ; Gilbert v. Boak Fish Co., 86 Minn. 365, 90 N.W. 767 (1902); Hahl v. Sugo, 169 N.Y. 109, 62 N.E. 135 (1901) ; James, Trial by Jury ard the New Federal Rules of Procedure, 45 Y ALE L.J. 1022, 1026 n.29 (1936).

55. N.Y. Sess. Laws ch. $379, \S 208$ (1848). The present provision is not greatly different. N.Y. CTV. PRAC. ACT \& 425 (1920); neither is the provision which will become effective an September 1, 1963. N.Y. CIv. PrAC. L. R. § 4101 (1962).

56. N.Y. Sess. Laws ch. 379, \& 221 (1848). Cf. N.Y. Crv. PrAc. Acr § 426 (1920); N.Y. Civ. Prac. L. R. § 4102 (1962, eff. Sept. 1, 1963).

As conservative as this provision seems to the modern eye, it was something of a novelty when first proposed in 1848. Its authors were "inclined to think, that parties will frequently 
These provisions proved unsatisfactory; the former because it specified the action as the unit to be dealt with rather than the component issues ${ }^{\text {it }}$ the latter because it often failed to settle the question of jury trial until the time of the trial and also because it required affirmative steps for waiver, so that inertia or sloth might yield jury trial where there was indifference to the question rather than any active desire for a jury by either party.

The defects in the waiver provision proved exceedingly disruptive of the orderly administration of justice. Trial calendars cannot be efficiently ordered if it is not known until the very time of trial which cases are going to require a jury. ${ }^{58}$ Indeed, it was not perfectly clear in all states that a party waived a jury by going to trial before the court alone without objection ${ }^{50}$ (so that he might both gamble on the outcome of the court trial, and object on appeal to deprivation of his jury right if the trial judge found against him). Moreover, the older type of provision put the weight of inertia on the side of the more expensive and dilatory mode of trial. These defects have been felt most keenly where trial dockets are crowded and delays-particularly in jury cases -are great. ${ }^{60}$

Because of the disadvantages of the earlier provisions some of the later codes (notably that of Connecticut) ${ }^{61}$ and the Federal Rules of Civil Procedure ${ }^{62}$

avail themselves of this permission." They mention several kinds of cases where they thought the parties would prefer a court trial : cases where evidence is largely documentary or the questions largely ones of law; cases respecting title to land, of insurance, or concerning commercial paper, or requiring consideration of foreign law. They point out that in the limited class of cases where the parties were theretofore free to choose the mode of trial, court trial had been "the more commonly chosen" (the figures cited put the preference at nearly 20 to 1 ). They end their note by this comment:

One of the most burthensome duties of the citizen, is the performance of jury scrvice. If that burthen can be lessened, by the plan proposed, without in any way infringing upon the rights of parties, we shall regard it as a great benefit.

First RePort of CoMmisstoners $189-90$.

57. See text accompanying notes 110-13 infra.

58. See, e.g., Platt v. Havens, 119 Cal. 244, 51 Pac. 342 (1897); Farwell v. Murray, 104 Cal. 464, 38 Pac. 199 (1894), described in James, supra note 54, at 1045.

59. See, e.g., Shaw v. Kent, 11 Ind. 80 (1858). Cf. Jackson v. Strong, 222 N.Y. 149, 118 N.E. 512 (1917).

60. The New York experience is illuminating. In 1920 the legislature declined to change the original scheme for waiver. See note 56 stupra. In 1927, however, it yielded to pressure and amended the act to require affirmative jury trial claim in New York and Bronx countics only. N.Y. Sess. Laws ch. 696 (1927). This provision was extended to all metropolitan counties in 1929. See Clark, Code Pleading \$ 17, p. 116 n.108 (2d ed. 1947). Further extensions (e.g., Westchester, Suffolk counties) occurred between that time and the adoption of the new Civil Practice Law. The latter requires affirmative claim in all jury cases and provides: "If no party shall demand a trial by jury as provided herein, the right to trial by jury shall be deemed waived by all parties." N.Y. CIv. PRAC. L. R. § 4102(a) (1962, eff. Sept. 1, 1963).

61. The present provision appears in ConN. GEN. STAT. $\$ 52-215$ (1958). It was first adopted in 1879, but has remained substantially unchanged except that the present statute provides for a jury of six unless the demand, or court order, specifies a full jury of 12 .

62. Fed. R. Crv. P. 38(d), 39(b). 
have adopted a different type of provision to govern the mode of trial and the matter of waiver of right to jury. The salient features of these later provisions are these:

(1) They do not set up a self-contained test for matters triable to a jury, but expressly adopt the constitutional test either by direct reference or by a simple reference to history.

(2) They specify the issue rather than the entire action as the unit to be dealt with in determining the right to jury trial, thus explicitly providing for the trial of some issues to the court and other issues to a jury, all in the same civil action. ${ }^{63}$

(3) They require an affirmative demand for jury trial at some pre-trial stage in the action and provide for waiver of jury trial in cases where no such demand is made, ${ }^{04}$ thus isolating at a time well before trial those cases where there is to be a jury trial or a problem about jury trial.

Fundamentally, both the older and newer types of provision seek to embody the historical test (for right to jury trial)which is embodied in the constitutions. It is true that the early codes sought to give a self-contained definition of actions triable to a jury but these definitions were probably meant, and have generally been interpreted, to be simply declaratory of the common law. What this means is that the architects of the united procedures took a neutralist position with respect to jury trial. ${ }^{65}$ Like the constitutions, they sought to preserve it where it previously existed. But they did not intend their procedural reform to extend jury trial any more than the framers of the constitutions intended the guaranty of jury trial to extend its scope.

63. E.g., FED. R. CIv. P. 42.

64. In Connecticut the demand is timely if made either within $\mathbf{3 0}$ days after the return day or within 10 days after an issue of fact is joined. Cons. Gen. Stat. § 52-215 (1958).

Under the federal rules the demand must be served upon the other parties "at any time after the commencement of the action and not later than 10 days after the service of the last pleading directed to such issue." FED. R. CIv. P. 38(b).

65. See notes 71-73 infra and accompanying text. The architects of the original New York Code, although they did not approve unqualifiedly of jury trial and hoped that their provision for waiver would diminish its use (note 56 stpra), nevertheless did contemplate some extension of jury trial, probably as a result of the jury trial provision which they proposed (set forth in text, at note 55 supra). See FIRST REPORT or Cosrurrssioxers 185 (comment following proposed $\S 208$ ends with following sentence: "We propose an extension of the right of trial by jury to many cases, not within the constitutional provision.").

Judge Clark has suggested that this sentence may have referred to specific extensions of jury trial by statutes other than the Code. CLARK, CODE PLEAding $\$ 16$, at $99 \mathrm{n} .60$ (2d ed. 1947). But New York courts have construed the Code as in fact extending the jury trial right. Susquehanna S.S. Co. v. A.O. Andersen \& Co., 239 N.Y. 285, 146 N.E. 381 (1925). The almost-if not quite-universal repudiation of these results outside of New York, however [see James, Trial by Jury and the New Federal Rules of Procedure, 45 YaLE L.J. 1022, 1031-36 (1936) ; CLARK, CODE PleAdING § 16, at 98-101 (2d ed. 1947)], and their recent repudiation-in part at least-in New York (See notes 113a \& 148 infro) argue strongly that if this was the intent of the New York Commissioners on this point, it was not widely shared by the framers of other codes. At any rate, any doubt which may be generated by the original New York provision and its progeny are foreclosed by the clear wording of provisions like those of Connecticut and the Federal Rules. See notes 61-62 sipra. 
The historical test, though widely accepted as the basis for solution, poses certain problems. Some of them are purely practical; one goes much deeper. On the practical level, it appears that history is sometimes equivocal. ${ }^{00}$ Moreover even where history is clear, analogies drawn from the divided procedure cannot be matched exactly with the situations that arise under a merged procedure, ${ }^{67}$ so that the precise application of history is hard or even impossible. Probably because of these difficulties attempts have been made to reduce the historical test to rules of thumb which will provide readier (but not essentially different) solutions to many of the aspects of the jury trial problem. The early code definitions represent one such attempt; ${ }^{68}$ Professor Moore's basicnature-of-the-issue test ${ }^{69}$ currently represents another.

The deeper difficulty with the historical test is that it tends to foreclose renewed and continuing judicial inquiry into the suitability of different types of issues for jury trial in a modern context. To a certain extent-as we have seen -the constitutions themselves foreclose such inquiry. And perhaps it may be assumed that the distinction between law and equity-though it did not to any great extent arise from this consideration-came in time to reflect, at least in part, the pragmatic judgment by wise and experienced men of what matters were suitable for jury trial. Nevertheless, as we have seen, ${ }^{70}$ in many cases a chancellor came to try issues which would customarily be for a jury for reasons which made perfectly good sense under the limitations of a divided procedure but have nothing to do with suitability of jury trial and which have no continuing vitality under a united procedure. Hence, some changes would seem to be desirable.

For the most part, any argument along this line must be addressed to those bodies entrusted with the power to amend constitutions, or to legislatures, or to courts in their rule-making (rather than their adjudicative) capacity. For good or evil, both the constitutions and the charters of the merged procedure embody the policy judgment, quite deliberately made, to leave the extent of jury trial about where history had come to place it. It may well be doubted whether it lies within the proper sphere of the judicial process to nullify that judgment, although there should be some room for these considerntions in interpreting statutes and rules (as well as constitutions) and in resolving doubtful lessons of history.

\section{The Types of Situations in Which Jury Trial Problem is Prescnted}

1. Civil actions which are counterparts of former law actions or equity suits

Many suits today are, from summons to judgment, no more than the counterpart of a former action at law. The typical personal injury suit furnishes a

66. See, e.g., the majority and dissenting opinions in Damsky v. Zavatt, 289 F.2d 46 (2d Cir. 1961); Swanson v. Alworth, 168 Minn. 84, 209 N.W. 907 (1926). Cf. City of Syracuse v. Hogan, 234 N.Y. 457, 138 N.E. 406 (1923); C.E.C., Comment, 32 Y ALE L.J. 707 (1923).

67. See notes 116-30 infra and accompanying text.

68. See notes $55 \& 65$ stpra and accompanying text.

69. 5 Moore, Federal Practice $\{38.16$ (2d ed. 1951).

70. See, e.g., text at notes 39-47 supra. 
ready example. Other suits present throughout only such facts and claims as would clearly have been cognizable in equity. A suit to foreclose a mortgage is a good illustration. ${ }^{71}$ In cases like these there is no greater jury problem today than there was under a divided procedure. Such right exists where it did before, and not otherwise.

It is true that statutes of the early code type might have given trouble even in these simple cases. A suit for an accounting between partners could quite literally be described as one"for the recovery of money only." A bill for specific performance of a contract to convey realty had as its ultimate objective nothing more or less than "the recovery ... of specific real property." And so it was with all cases where plaintiff claimed money or property on the ground of some right, title, or interest which only equity would recognize. But, with virtual uniformity, these statutes were not construed in this literal manner; rather they were interpreted in the light of history. Such a ". . provision is no broader than the provision of the Constitution."72 In all the situations described in this paragraph, therefore, jury trial was denied. ${ }^{73}$

The problems peculiar to a united procedure are presented by that peculiar product of union, the civil action that contains more in the way of claims or defenses than any suit could have contained in the old days. The case may be one where a plaintiff injects both legal and equitable claims, or where an equitable defense or counterclaim is interposed to an action presenting only legal issues, or vice versa. And there may be combinations of these situations in a single action.

\section{Civil actions where plaintiff injects both legal and equitable claims}

\section{a. Historical patterns}

There were several different situations under the former procedure where a suitor needed both equitable and legal relief to get complete redress for his injury. There were other types of situations where the suitor had a choice of remedies. There were still others where he had only one remedy but mistakenly

71. At least where no deficiency decree is sought. See notes 36-37 supra and accompanying text.

72. Morton Brick \& Tile Co. v. Sodergren, 130 Minn. 252, 254, 153 N.W. 527, 528 (1915).

73. Accounting: United Coal Co. v. Canon City Coal Co., 24 Colo. 116, 48 Pac. 1045 (1897) ; Morton Brick \& Tile Co. v. Sodergren, supra note 72; Ely v. Coontz, 167 Mfo. 371,67 S.W. 299 (1902).

Specific performance (realty): Davis v. Judson, 159 Cal. 121, 113 Pac. 147 (1910); cf. Hamilton v. Hamilton, 59 Mo. 232 (1875).

Claims to money or property on equitable grousids: Cree v. Lewis, 49 Colo. 186, 189, 112 Pac. 326 (1910) ("True, plaintiff demanded and was given a money judgment, but this relief depended upon the establishment of a trust.") ; Conran v. Sellew, 28 2ro. 320, 322 (1859) ("These provisions manifestly makes a distinction between suits which were formerly recognized as actions at law, and bills in equity; and the mode of trial in a given case under the present code may generally be determined by ascertaining whether under the old system it would be cognizable at law or in equity.")

See also CLARK, Code PleadrNg § 16, at 99-101. 
pursued the other. The differences among these were important because different patterns of trial and trial sequence were applied.

In one class of cases a suitor had to resort to equity first to get any relief, or to get full relief. Where an instrument to which $A$ and $B$ were parties did not, as it was written, support any legal claim by $A$ and $A$ also claimed that the writing failed by mutual mistake to embody the actual agreement of the parties, which would support A's legal claim if it had been embodied in the instrument, then $A$ could get nowhere in a court of law unless and until equity decreed a reformation of the instrument. This was not the kind of mistake which the common law would remedy; it would simply enforce the instrument as written. ${ }^{74}$ If the chancellor found mutual mistake, he would not only decree reformation but would also settle any remaining issues pertinent to A's right to relief under the instrument as reformed and award relief. ${ }^{75}$ At least the chancellor would do all that if $A$ asked him to. ${ }^{70}$ If the chancellor found no mutual mistake he would dismiss the bill, leaving the parties to any remedy they might have at law. ${ }^{77}$ In the illustration put, that would be none; but there were cases where either the equity plaintiff, $A$, or his adversary, $B$, would have some legal remedy under the instrument as written. In this type of case if B sued A at law under the instrument as written, the chancellor would enjoin the prosecution of this legal action until the question of mutual mistake had been determined. ${ }^{78}$

Let us call this pattern of behavior Pattern I. In it the equitable issue would always be tried first and tried without a jury. ${ }^{70}$ Neither of the parties had a choice about this nor did the equity court have any real discretion since a temporary injunction against prosecution of the law action would issue as a matter of course. ${ }^{80}$ Moreover, the equitable issue (mutual mistake) was one

74. Compare Capital City Bank v. Hilson, 59 Fla. 215, 51 So. 853 (1910) (contract as written supports no legal judgment on facts) with Capital City Bank v. Hilson, 64 Fla. 206, 60 So. 189 (1912) (complaint held to show basis for reformation of same contract and for recovery of damages). Compare also Franklin Fire Ins. Co. v. Hellerick, $20 \mathrm{Ky}$. L. Rep. 1703, 49 S.W. 1066 (1899) (no recovery where burned building not within policy description) with Hillerich v. Franklin Ins. Co., 111 Ky. 255, 63 S.W. 592 (1901) (amendment presenting basis for reforming same policy held improperly denied).

75. Kelly v. Galbraith, 186 Ill. 593, 58 N.E. 431 (1900); Keith v. Henkleman, 173 Ill. 137, 50 N.E. 692 (1898); Capital City Bank v. Hilson, 64 Fla. 206, 60 So. 189 (1912); Annot., 66 A.L.R. 763, 777-87 (1930); 1 Pomeroy, Equity Jurisprudence $\$ 237 \mathrm{c}$ (5th ed. 1941).

76. See note 22 supra and accompanying text.

77. 1 POMEROY, op. cit. supra note 75, § 237d.

78. See, e.g., Liberty Oil Co. v. Condon Nat. Bank, 260 U.S. 235, 242-43 (1922); cf. Enelow v. New York Life Ins. Co., 293 U.S. 379 (1935); American Cyanamid Co. v. Wile son \& Toomer Fertilizer Co., 62 F.2d 1018 (5th Cir. 1933).

79. Unless, of course, the defendant at law was unaware of the pendency of the law suit, or of his own equity, or for some other reason failed to resort to equity before judlgment in the action at law. It was the issuance of injunctions in such situations that precipitated the Coke-Ellsmere struggle and finally established the ascendancy of equity.

80. Young v. Reynolds, 4 Md. 375 (1853) ; Hibbard v. Eastman, 47 N.H. 507 (1867) ; 1 Pomeroy, EQuity JuRISPRUdence 370, 371, 375 (5th ed. 1941) ; 4 id. \$\$ 1362, 1363, 1364 (4th ed. 1919). 
which law courts did not recognize. Finally, if the equitable issue was decided in favor of $A$, there would be no second suit and thus no jury trial of any issue. 81

At the opposite pole was a class of cases in which equity refused to give relief unless and until a preliminary legal issue had been determined at law by a jury, yet where equitable relief was needed for plaintiff's complete protection. Where A claimed that B's structure encroached on A's land but B also claimed title to the land under the structure, equity would not order the structure removed until the title dispute was settled at law. ${ }^{82}$ If $\mathrm{A}$ won the law action, equity would order $B$ to remove the structure if it was impractical for the sheriff to remove it under a writ of execution. ${ }^{83}$ Again, where A claimed that $B$ owed him a legal debt and wished to reach B's equitable assets, or property conveyed by $B$ to $C$ to defraud $B$ 's creditors, equity would grant no relief if $B$ disputed the debt until $A$ had reduced his debt claim to a judgment at law. ${ }^{84}$ Then, at least if execution could not be satisfied, equitable relief would be forthcoming on a proper showing. ${ }^{85}$

Let us call this pattern of behavior Pattern II. In it, equity would refuse to try the legal issue; and the legal issue would always be tried first..$^{80}$ If the trial was won by A, he still would often need a second suit in equity to get complete relief. Thus there would be two trials, one to a jury, and one to a court alone on those issues which pertained to the propriety of equitable relief. Again, neither party had any choice in the matter, and the courts had no discretion.

Between these two fairly clear-cut patterns lay a host of others in many of which either kind of relief depended on the resolution of an issue which either tribunal would try (with its own mode of trial). Thus B's violation of A's statutory right (e.g., to a patent or copyright) might entitle $A$ to an injunction, to compensatory damages, and to a penalty. The right to any relief would turn on whether $B$ violated the statute. A might get a determination of that issue without a jury in an equity suit, seeking an injunction and perhaps compensatory damages as incidential to an injunction. ${ }^{87}$ Or he might get such de-

81. See note 75 supra. But see text at note 76 supra.

82. See cases cited note $\mathbf{5 0}$ supra.

83. Ibid.

84. See e.g., Case v. Beauregard, 101 U.S. 688, 690-91 (1879) ; Pusey \& Jones Co. v. Hanssen, 261 U.S. 491, 497 (1923) ; Southard v. Benner, 72 N.Y. 424,426 (1878); American Surety Co. v. Conner, 251 N.Y. 1, 166 N.E. 783 (1929) (dealing with change wrought by Uniform Fraudulent Conveyance Act, and also prior law) ; 5 Posreroy, Eourry JUrIsPRUDENCE \$§ 2294-2318 (871-895) (particularly § 2305 (882)) (4th ed. 1919) (this part, which was originally J. N. Pomeroy, Jr.'s EQuitable Reuredres, does not appear in the 5th edition of PoMreroy, EQuTtable JurisprudencE).

85. Ibid.

86. The rules themselves were not without exceptions which warranted equitable relief without first establishing the legal right at law, as the cases cited in notes 50 \& 84 show. Unless, however, the case could be brought under one of these exceptions the legal issue would always be tried first.

87. Brady v. Daly, 175 U.S. 148 (1899); Marsh v. Seymour, 97 U.S. 348 (1877); see Barton v. Barbour, 104 U.S. 126, 133-4 (1881) ; 35 U.S.C.A. \$283 note 197. 
termination in an action at law for damages or for the penalty. ${ }^{88}$ Since equity refused to enforce a penalty ${ }^{80}$ and the law would not give an injunction, two suits would be required for complete relief. A had the choice which to bring first. And the first determination of the common issue (violation vel non) would bind the parties in the second action..$^{00}$ The plaintiff then had the power to choose the mode of trial of the common issue, and he could so exercise it as to leave no room for judicial discretion.

If the statute did not provide for a penalty, $\mathrm{A}$ might be able to get complete relief in a suit in equity. ${ }^{91}$ But he would also have the option to stle for damages at law and for an injunction in equity separately, in whichever order he chose. So here again A could control the mode of trial of the common isste, without leaving room for judicial discretion.

In another class of cases $A$ also had a choice, but it was a more limited one. Breach of certain kinds of contracts (e.g., to convey land) would entitle the injured party to either specific performance ${ }^{22}$ (with incidental damages for delay of performance, and the like) or to damages for breach ${ }^{83}$ (measured on the assumption that the contract would not be performed). Here A could in no case get both forms of relief-he had to elect one or the other, ${ }^{04}$ His election would govern the mode of trial of issues, such as making ${ }^{05}$ of the contract, performance of conditions precedent, breach,,$^{96}$ and the like, which would be presented in a claim for either kind of relief.

88. Bereslavsky v. Caffey, 161 F.2d 499 (2d Cir. 1947) ; Bruckman v. Hollzer, 152 F.2d 730 (9th Cir. 1946) ; Berlin v. Club 100, Inc., 12 F.R.D. 129 (D. Mass. 1951) ; Pallant v. Sinatra, 7 F.R.D. 293 (S.D.N.Y. 1945) ; Bellavance v. Plastic-Craft Novelty Co., 30 F. Supp. 37, 38-39 (D. Mass. 1939), Davies v. Allied Industrial Prod., Inc., 100 F. Supp. 109 (N.D. Ill. 1951). But cf. Chappell \& Co. v. Palermo Cafe, Inc., 146 F. Supp. 867 (D. Mrss. 1956). The statutory provision for an "action on the case" for damages for patent infringement was repealed in 1948. 62 Stat. 992, 35 U.S.C.A. App. II § 67. Under the amendment the parties are entitled to jury trial of the issues raised by a claim for damages, even where it is coupled with a claim for injunction. National Dryer Mfg. Co. v. Dryer Co. of Am., $130 \mathrm{~F}$. Supp. 912 (E.D. Pa. 1955) ; Inland Steel Prod. Co. v. MPH Mfg. Co., 25 F.R.D. 238, 245.46 (N.D. Ill. 1959).

89. Decorative Stone Co. v. Building Trades Council, 23 F.2d 426 (2d Cir. 1928).

90. Brady v. Daly, 175 U.S. 148 (1899); Bruckman v. Hollzer, 152 F.2d 730 (9th Cir. 1946) ; cf. Beacon Theatres v. Westover, 359 U.S. 500 (1959).

91. See note 87 sipra.

92. 5 Corbin, Contracts ch. 63 (1951).

93. Id. $\$ 990$ and, generally, chs. 55-60.

94. Rushing v. Mayfield Co., 62 F.2d 318 (5th Cir. 1932), cert. destied, 289 U.S. 750 (1933) ; cf. 5 Corbin Contracts $\$ 1222$ (1951).

95. Rash v. Peoples Deposit Bank \& Trust Co., 192 F.2d 470 (6th Cir. 1951) ; Canister Co. v. Leahy, 182 F.2d 510 (3d Cir. 1950) ; Mahon v. Bennett, 81 F. Supp. 901 (W.D. Mo. 1948) ; Fraser v. Geist, 1 F.R.D. 267 (E.D. Pa. 1940) ; Trenchard v. Reny, 70 Utah 19, 257 Pac. 1046 (1927); Morris, Jury Trial under the Federal Fusion of Lazu and Equily, 20 TEX. L. REv. 427,428 (1942).

96. See, e.g., Altoona Electrical, Eng'r. \& Supply Co. v. Kittanning \& F. C. St. Ry, 126 Fed. 559, 561 (C.C.W.D. Pa. 1903) (substantial performance found by court on "a great conflict between the witnesses." Id. at 562.). 
In the case just put, if $A$ initially chose equitable relief, the chancellor might find that specific performance was impossible or unsuitable even where there might have been a breach of contract. Where the ground of equitable relief failed in this manner, the court would usually dismiss the suit for want of "equity jurisdiction,"97 leaving A free to pursue legal relief in a law court with its jury. The chancellor would not, however, always dismiss a case when specific performance was denied. In Denton $v$. Stewart, ${ }^{88}$ defendant transferred the subject matter of the contract (a leasehold) to an innocent purchaser after the equity suit was begun. This was held to frustrate the granting of specific performance; but to save plaintiff from the hardship of a second action, the chancellor determined the issues and awarded damages. This granting of substituted legal relief in equity was exceptional in late eighteenth century England and may not have extended beyond the case of impossibility arising after suit. ${ }^{29}$ The notion has enjoyed considerable growth since then, ${ }^{100}$ however, and has even been applied occasionally where specific performance was denied because the contract was unconscionable by equitable standards. ${ }^{101}$

\section{b. Modern patterns}

The application to the current scene of Patterns I and II has not given much trouble. There is not, and should not be, in these cases any talk of the court's discretion in directing the order of trial of the issues. If any fidelity to history whatever is observed, the equitable issue will be tried first in Pattern $I,{ }^{103}$ the legal issue in Pattern II. ${ }^{103}$ In Pattern I, history is reinforced by common sense. If there is a question whether an instrument should be reformed, that question must necessarily be settled before an intelligent inquiry may be made into the parties' rights under the alleged agreement.

Possible difficulties in the application of Pattern I may be presented by:

(a) a question whether an issue once exclusively equitable has worked over into law.104

(b) a question whether plaintiff, if he is entitled to equitable relief, is also entitled to jury trial of residual legal issues. It is commonly assumed that he would not be, since equity, if it took initial jurisdiction, would settle all issues in the controversy as incidental to that jurisdiction. ${ }^{105}$ But this overlooks the fact that equity would do this, historically, only if plaintiff requested it. ${ }^{100}$

97. Todd v. Gee, 17 Ves. Jr. 273, 34 Eng. Rep. 106 (Ch. 1810) ; Mrarlss v. Gates, 154

Fed. 481, 484 (9th Cir. 1907); Flattau v. Logan, 72 N.J. Eq. 338, 65 Atl. 714 (1907).

98. 1 Cox Ch. 258, 29 Eng. Rep. 1156 (Ch. 1786).

99. See Todd v. Gee, note 97 supra; Milkman v. Ordway, 105 Míss. 232, 253 et seq (1870) ; Levin, Equitable Clean-Up and the Jury: A Suggested Orientation, 100 U. PA. L. REv. 320, 333-4 (1951).

100. See note 27 supra and accompanying text.

101. Gabrielson v. Hogan, 298 Fed. 722 (8th Cir. 1924) ; cf. Morgan v. Dibble, 43 Cal.

App. 116, 184 Pac. 704 (1919) ; see Levin, op. cit. supra note 99, at 339.

102. See notes 75-79 supra and accompanying text.

103. See notes $82-86$ supra and accompanying text.

104. See note 31 supra.

105. See notes 23 and 24 supra.

106. See note 22 supra. In Austin v. Brooklyn Cooperage Co., 285 S.W. 1015 (Afo. App. 1926), a plaintiff was given this option without any discussion of historical antecedents. 
(c) a question whether, if equitable relief is denied, either party would have a right to jury trial of any issues presented by the instrument as written. This he should have, ${ }^{107}$ unless the case is treated as falling within a latter-day extension of substituted legal relief in equity, ${ }^{108}$ or unless the right is waived.

(d) a question of waiver of jury trial by failure to claim it as prescribed by statute or court rule. If there is such a waiver in the pleading stage, it should not be relieved by later failure of the equitable claim if that failure - and the consequent emergence of legal issteswas foreseeable to the party now claiming a jury at the time of waiver. ${ }^{109}$

(e) a question whether plaintiff may waive any jury trial right he may have because he has joined claims for legal and equitable relief. In New York such joinder has been consistently held to constitute such a waiver. ${ }^{110}$ This rule results from an unfortunate construction put upon the early jury trial statute. Since plaintiff has included an equitable claim, the "action" is no longer one within

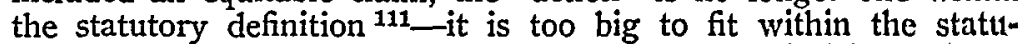
tory pigeon-hole, so to speak. By making it so, plaintiff has thereby waived his jury right. Such a result is seldom reached elsewhere even under similar statutory provisions; $;^{\mathbf{1 1 2}}$ it can scarcely be reached under the Federal Rules and their counterparts. ${ }^{118}$ It has been repudiated, at least in part, in the new Civil Practice Law. ${ }^{118 a}$

(f) a question whether Pattern I, and indeed much of former equity jurisdiction, has been abolished as a guide in solving the jury trial problem by the creation of the declaratory judgment remedy. This question has perhaps been raised by recent language of the United States Supreme Court.114

107. Union Central Life Ins. Co. v. Burger, 27 F. Supp. 554 (S.D.N.Y. 1939) ; Park v. Wilkinson, 21 Utah 279, 285, 60 Pac. 945, 946 (1900).

108. See notes $26,27,100$ and 101 sipra.

109. Moore v. United States, 196 F.2d 906 (5th Cir. 1952) ; Gulbenkian v. Gulbenkian, 147 F.2d 173 (2d Cir. 1945); Indianapolis Northern Traction Co. v. Brennan, 174 Ind. 1, 90 N.E. 65 (1909).

110. Cogswell v. New York, N.H. \& H. R.R., 105 N.Y. 319, 11 N.E. 518 (1887) ; DiMenna v. Cooper \& Evans Co., 220 N.Y. 391, 115 N.E. 993 (1917).

111. See note 55 supra.

112. Moore v. San Vicente Lumber Co., 175 Cal. 212, 165 Pac. 687 (1917) ; Hughes v. Dunlap, 91 Cal. 385, 27 Pac. 642 (1891); Austin v. Brooklyn Cooperage Co., 285 S.W. 1015 (Mo. App. 1926).

113. Ring v. Spina, 166 F.2d 546 (2d Cir. 1948); Bruckman v. Hollzer, 152 F.2d 730 (9th Cir. 1946) ; Roy v. Moore, 85 Conn. 159, 82 Atl. 233 (1912).

113a. N.Y. Civ. PRAC. L. R. § 4102(c) (1962) provides in part: "A party shall not be deemed to have waived the right to trial by jury of the issues of fact arising upon a claim, by joining it with another claim with respect to which there is no right to trial by jury and which is based upon a separate transaction ...." It is doubtful whether the claims in Cogswell and Di Menna, sipra note 110, should be regarded as "based upon separate transaction [s]."

114. Beacon Theatres v. Westover, 359 U.S. 500 (1959), discussed in text accompanying note 182 infra. 
Possible difficulties in the application of Pattern II may be presented by:

(a) a question whether an issue once exclusively legal has worked over into equity. Such instances have been noted above.116

(b) a question whether plaintiff waives his historical (and constitutional) jury trial right by joining legal and equitable claims. This is the third question we noted in discussing Pattern I.

In the third group of cases discussed in the last section (which is too hetrogeneous to be called a pattern) there is a common issue, or set of issues, which is determinative of both forms of relief and which either law or equity would try under some circumstances. Here again pre-merger patterns of judicial behavior are helpful in determining the mode of trial of the common issue.

In cases such as patent or copyright infringement, where plaintiff is entitled to cumulate legal and equitable remedies, he had an option as to the mode of trial which excluded any option by defendant or any discretion by the court. Plaintiff exercised this option by seeking his remedies in separate suits, and bringing them in the order he chose. Today under merger, plaintiff must seek in a single suit all relief arising out of a single group of operative facts $;{ }^{110}$ thus the traditional manner of exercising his option is no longer available. But it would be inconsistent with the preservation of his jury right, embodied in both the constitutions and the charters of the merged procedures, to take away the substance of the option. The problem is simply one of finding a substitute method of exercising it which is consistent with the other objectives of merger. It has been suggested that this method may be the drafting of the complaint in separate counts for the legal and equitable relief. ${ }^{117}$ But this seems to put undue stress on form. ${ }^{118}$ The best solution, it is submitted, is to let plaintiff express his choice of jury trial by simply claiming it in the way provided by statute or rule.

In either event the plaintiff would be given his jury option freed from the old burden of having to bring two actions to secure it. It may be objected that plaintiff would thus get an undeserved windfall. But double litigation was a burden on defendants and on society as well, and no great harm will result from freeing all parties from it and at the same time preserving plaintiff's jury right.

The defendant had no choice of mode of trial in the situation under discusion. The only justification for giving him any choice today would be a desire to extend, rather than merely preserve, his jury trial right. Nevertheless a federal court of appeals has held that a defendant is entitled to jury trial of the common issue in such a case $;^{110}$ the Supreme Court has recently cited this decision, apparently with approval. ${ }^{120}$ Both these cases disapproved earlier

115. See notes 20-27 supra and accompanying text.

116. See note 54 stipra.

117. See Russell v. Laurel Music Corp., 104 F. Supp. 815, 816 (S.D.N.Y. 1952).

118. Cf. McCoid, Right to Jury Trial in the Federal Courts, 45 Iows L. Rev. 726, 728-31 (1960).

119. Leimer v. Woods, 196 F.2d 828 (8th Cir. 1952).

120. Beacon Theaters v. Westover, 359 U.S. 500, 511 (1959). 
decisions which left the mode of trial to the trial court's discretion, ${ }^{121}$ a ruling which is equally indefensible historically and could result in curtailing the plaintiff's constitutional right (as well as in extending the defendant's).

The most troublesome problems in cases where a plaintiff injects both legal and equitable claims into a civil action are found in the specific performance situations. Fomerly, as we saw, plaintiff could have only one of the remedies and he had to pursue it in the appropriate fortum. He could not pursue them alternatively in a single suit.122 And the dismissal of the equity suit because specific performance was inappropriate would not bar a later action at law for damages. ${ }^{123}$ The merged procedure has changed some of this. Plaintiff may still have only one of the remedies, ${ }^{124}$ but he both may ${ }^{125}$ and must ${ }^{120}$ pursue all of his remedies (arising from a single breach of contract) in a single action, and he may do so alternatively (exercising the necessary choice between the remedies after trial). ${ }^{127}$ Further, the court is empowered and directed in most situations to award appropriate relief even where it has not been claimed in the complaint. ${ }^{128}$ Question then arises as to jury trial right on common dispositive issues (e.g., contract vel non, etc.) in the single civil action which plaintiff may bring, wherein he expressly pursues both remedies in the alternative or wherein the court may find appropriate and award a remedy not expressly demanded.

One suggestion is to let plaintiff's right be governed by plaintiff's preference as to the kind of relief. Professor Moore would apply a rule of thumb for determining this preference: equitable relief is deemed preferred if expressly claimed. ${ }^{129}$ Professor Morris has tried to refine the test. ${ }^{130}$ The former seems

121. American Life Ins. Co. v. Stewart, 300 .U.S. 203 (1937); Orenstein v. U.S., 191 F.2d 184, 190 (1st Cir. 1951). See also Tanimura v. United States, 195 F.2d 329 (9th Cir. 1952).

122. Rushing v. Mayfield Co., 62 F.2d 318 (5th Cir. 1932), cert. denicd, 289 U.S. 750 (1933).

123. Logan v. Flattau, 73 N.J. Eq. 222, 67 Atl. 1007 (1907) (after dismissing bill for specific performance, equity will not enjoin action at law) ; cf. Pomeroy, SpectFic PerrorarANCE OF CONTRACTS $\S 475$ (3d ed. 1926).

124. 5 Corbin, Contracts $\$ 1222$ (1951) (a party "should not be allowed to enforco and receive specific performance and at the same time get judgment for damages for a total breach.").

125. San Diego Water Co. v. San Diego Flume Co., 108 Cal. 549, 41 Pac. 495 (1895); Sternberger v. McGovern, 56 N.Y. 12 (1874); cf. Poneroy, Specific Perronurance or Contracts $\$ 480$ ( 3 d ed. 1926).

126. See note 54 supra.

127. Fed. R. Civ. P. 8(a) (3) ; 2 Moore, Federal Practice $\| 8.18$ (2d ed. 1948, Supp. 1962) ; cf. Morris, Jury Trial under the Federal Fusion of Law and Equity, 20 TEx. L. REv. 427, 430-33 (1942).

128. Fed. R. Civ. P. 54(c) ; N.Y. Civ. Prac. Act § 479; N.Y. Civ. Prac. L. R. § 3017 (a) (1962).

129. 5 Moore, Federal Practice $\llbracket 38.21$ (2d ed. 1951, Supp. 1962). Cf. Fraser v. Geist, 1, F.R.D. 267 (E.D. Pa. 1940).

130. Morris would require a plaintiff who claims damages and specific performance alternatively to state his preference when jury trial is demanded. If he prefers damages, a 
unduly restrictive of plaintiff's jury right; the latter unduly difficult to administer.

As for defendant's right to a jury, it may come into play if the ground for equitable relief fails or if plaintiff (being entitled to either relief) elects after trial to take damages. The serious questions are: (a) whether the case would have been one for substituted legal relief in equity and, if not, (b) whether defendant will be allowed to exercise his jury trial right after the failure of equitable grounds or after plaintiff's election of damages.

If the chancellor would have given substituted legal relief at the time referred to in the constitutional guaranty of jury trial, then defendant has no right to a jury. But we have noted an American tendency to expand the concept beyond that obtaining in England in 1791.131 This tendency raises the question, discussed above, ${ }^{132}$ of the extent to which the constitutional guaranty allows for flexible growth. Further, it should be noted that virtually the only significance of the doctrine of substituted legal relief in a merged procedure is its effect in curtailing jury trial. There should then be no justification for expanding the notion of substituted legal relief in equity after merger, as some American courts have done, except a desire to curtail jury trial, which is one of the very things the architects of merger did not intend to have their reformed procedure bring about.

It is true that if jury demands made after court trial are honored, this will disrupt the administration of justice and let a litigant gamble on the outcome of the first trial while being assured of a second if the first goes against him. But the cure for these evils is not to be found in the questionable extension of an archaic doctrine. Rather it is to be found in the waiver provisions expressly embodied in modern merged procedures. These, it is submitted, provide a reasonable solution for most of the problems presented by the specific performance situation, as well as by other situations where there is a failure of grounds for equitable relief but it appears that plaintiff may be entitled to legal relief. A jury must generally be claimed at a fairly early pre-trial stage, and it is waived if not so claimed.133 The solution proposed here would involve the following rulings, in combination:

(a) A ruling that waiver of jury trial under statute or rule will not be relieved against because of the emergence of legal claims based on facts which were pleaded at the time of the waiver. In the usual case plaintiff claims specific performance of a contract which

jury will be called at the start of the trial (and later dismissed if the damage theory becomes inadequate on some "purely legal" ground). If plaintiff prefers specific performance and wants jury trial only if his right to specific performance fails on "purely equitable" grounds, the judge should require him to state the fears which prompted the alternative claim. "On the basis of such an explanation, the judge can marshal the trial so that equities alone are dealt with first. The jury need not be called until the plaintiff's fears materialize." Morris, op. cit. supra note 127 , at $432,433$.

131. See notes $27,100 \& 101$ stpra and accompanying text.

132. See notes $36 \& 50$ supra and accompanying text.

133. See note 64 sipra and accompanying text. 
he claims was breached; defendant denies the contract, or the breach or both and claims specific performance is inappropriate anyhow. In this situation it is perfectly foreseeable to defendant that if the court should agree with his own claim about the inappropriateness of specific performance, the pleaded facts present a legal issue. Armed with this chance for foresight, defendant should not be allowed to withhold his jury claim without waiver. ${ }^{184}$

(b) As a corollary of this ruling, a court would deny a timely jury claim in such a case at peril of reversal if the case turned out so as to vindicate the claim. This might be either a plaintiff's jury claim (wherever he has not effectively renounced his legal remedy) or a defendant's claim under the circumstances described in the previous paragraph.

(c) This will mean that where a jury claim is made the court will often have a jury in attendance at the trial against the possibility that it may be needed. In this way it can assure jury determination of the potential legal issues and its own determination of equitable issues. ${ }^{135}$

If this procedure is followed it will mean that in some cases a jury will sit through a whole trial and then have no function to perform (e.g., where the court finds the common issues for plaintiff and awards specific performance). Having a jury "to dance attendance"136 may be wasteful. On the other hand, the expense of their attendance may be regarded as an insurance premium against the cost of retrials when matters turn out the other way; and the disappointed suitor has much to gain and little to lose by demanding a new trial before a jury. The procedure suggested above will not be adeqtate to handle the rare case where the emergence of legal claims could not reasonably be anticipated at the time provided for claiming jury trial. Bereslavsky $v$. Caffey ${ }^{137}$ was treated as presenting such a situation. The court held that where plaintiff's claim for equitable relief failed for reasons arising after suit and beyond his control, he was entitled to claim a jury after amending his complaint to omit the equitable claim. No doubt defendant would have the same right.

134. Gulbenkian v. Gulbenkian, 147 F.2d 173 (2d Cir. 1945) ; cf. Garland v. Garland, 165 F.2d 131 (10th Cir. 1947); Scholl v. Scholl, 152 F.2d 672 (D.C. Cir. 1945); note 109 supra.

This is essentially the same solution as that suggested in 5 Moore, Federar Practice đI 38.18 (2d ed. 1951).

135. In Fraser v. Geist, 1 F.R.D. 267, 269 (E.D. Pa. 1940), Judge Kalodner snid it was "regrettable that Rule 39 as presently phrased ..." precluded the solution suggested in the text, because (he believed) that rule "makes it incumbent upon the court to decide from the pleadings and prior to trial whether or not the action is one at law or in equity."

Other courts have found no such inhibition in Rule 39. See, e.g., Hargrove v. American Cent. Ins. Co., 125 F.2d 225 (10th Cir. 1942) ; Ford v. C. E. Wilson \& Co., 30 F. Supp. 163 (D. Conn. 1939). See also Clark, Code Pleading 106, 107 (2d ed. 1947); 5 Moore, FEderaI Practice $\llbracket 38.18 \mathrm{n} .5$ (2d ed. 1951) (the position taken in Fraser v. Geist "is not sound.").

136. Henry VIII, Act V, Sc. 2, 1.30.

137. 161 F.2d 499 (2d Cir.), cert. denied, 332 U.S. 770 (1947) ; cf. Bereslavsky v. Klocb, 162 F.2d 816 (6th Cir.), cert. denied, 332 U.S. 816 (1947). 
This seems a sensible solution where there was originally no basis for a jury claim. But that was not the case in Bereslavsky. ${ }^{138}$

\section{Civil action involving equitable defense to a legal claim}

\section{a. Historical pattern}

Certain matters, cognizable in equity, would defeat a legal claim but were not recognized at law and could not, therefore, be successfully pleaded in an action at law. ${ }^{139}$ If $A$, the obligor on a specialty, claimed that he was induced by fraud to execute it in favor of $B$, he could not interpose that fraud in B's legal action on the specialty. ${ }^{140}$ To get relief, $A$ would have to go into equity and seek cancellation of the specialty for the fraud. Equity would then enjoin the prosecution of the law suit temporarily until the question of fraud was determined. If the chancellor found fraud, he would decree cancellation of the specialty and make permanent the injunction against B's prosecution of the law action. ${ }^{141}$ Thus there would be no jury trial of any issue. The equitable issue would be tried first and dispose of the whole case, or where there were residual legal issues (as where the instrument was reformed rather than cancelled), equity would dispose of them as incidental to the equitable relief.12 It will be noted that the equitable relief, though always affirmative in form (cancellation, rescission, etc.) in most cases had only the effect of defeating the law action. ${ }^{143}$ If, on the other hand, the chancellor found no fraud, he would dismiss the equity suit, dissolve the temporary injunction, and leave the parties to their claims and defenses in the legal action. This pattern will be recognized as being essentially a variant of Pattern $I$, described above. ${ }^{114}$

One thing more should be noted before we leave history. Many matters which were cognizable only in equity in remote times came to be recognized as defenses by courts of law-worked over into law as we say-in the course of time. ${ }^{145}$ After this process had become complete, equity would typically refuse to enjoin the law action and grant relief, stating that the remedy at law was adequate. ${ }^{146}$ The equity plaintiff in any illustration could plead the matter as a defense in the law action.

138. Since the plaintiff originally claimed both legal and equitable relief, he should, at his option, have been given a jury trial upon demand. See text accompanying notes 117-18 supra. Since he did not claim it at that time, he should have been held to have waived it. See text accompanying note 109 sipra. See also Clark, Cases on Mfodern Pleading 596-97 (1952).

139. See the exposition in Cook, Equitable Defenses, 32 YALE L.J. 645 (1923); of. Abbott, Fraud as a Defence at Law in the Federal Courts, 15 CoLusr. L. Rev. 489 (1915); Hinton, Equitable Defenses under Modern Codes, 18 Mrrar. L. REv. 717 (1920).

140. George v. Tate, 102 U.S. 564, 570-1 (1880) ; Franchot v. Leach, 5 Cow. 506 (N.Y. Super. Ct., 1825) ; Belden v. Davies, 2 Hall 433 (N.Y. Super. Ct. 1829); Ames, Specially Contracts and Equitable Defences, 9 HARv. L. REv. 49, 51 (1895).

141. See Cook, supra note 139, at 649-50.

142. See note 24 supra and accompanying text.

143. See Cook, supra note 139 , at 650 .

144. See text accompanying note 74 supra.

145. Ames, supra note 140; Abbott, supra note 139; Hinton, supra note 139, at 721-23.

146. Cable v. United States Life Ins. Co., 191 U.S. 288 (1903); Abbott, supra note 139. 


\section{b. Modern patterns}

The prevailing pattern in merged procedures faithfully follows the historical pattern except that all steps occur in a single civil action and there is no injunction. When $B$ sues $A$ upon the legal claim, $A$ affirmatively pleads in that action the matter that would have been the subject of a separate suit in equity before the merger. What was accomplished by the temporary injunction under the old procedure is done under the new by a simple order that the equitable issues tendered by the answer (or counterclaim) be tried to the court and tried first. ${ }^{147}$ Since, as we have seen, ${ }^{148}$ a temporary injunction would issue as a matter of course in such a situation, there should be no room for judicial discretion today in the matter of trial sequence. ${ }^{149}$ And if the equitable issue is determined in A's favor, there is no historical basis for awarding $B$ a jury trial on any residual legal issues.

Possible difficulties in the application of this simple pattern may be presented by:

(1) a question whether the issue tendered by the defendant had worked over into law by the time of the merger.

(2) an attempt to distinguish between equitable defenses and equitable counterclaims. This is the product of another ill-starred piece of statutory construction confined largely to New York, and now repudiated there by the statute which will go into effect in the fall of 1963.150 It will be recalled that the New York Code treats the action as the unit to be dealt with in determining mode of trial.161 Other sections provide that all defenses (whether denials or affirmative defenses) simply raise an issue in the action, ${ }^{162}$ while counterclaims are to be treated as independent actions for this purpose. ${ }^{163}$ All defenses, therefore, are triable as the action is triable, while the

147. Weber v. Marshall, 19 Cal. 447 (1861) ; Bodley v. Ferguson, 30 Cal. 511 (1866); Davis v. Holbrook, 25 Colo. 493, 55 Pac. 730 (1898); Penninger Lateral Co., Ltcl. v. Clark, 22 Idaho 397, 126 Pac. 524 (1912) ; Piggly-Wiggly Stores v. Lowenstein, 197 Ind. 62, 147 N.E. 771 (1925) ; Price v. Chambers, 148 Wash. 170, 268 Pac. 143 (1928) ; cf. Liberty Oil Co. v. Condon Nat. Bank, 260 U.S. 235 (1922).

148. See note 80 supra.

149. But cf. Crosby v. Scott-Graf Lumber Co., 93 Minn. 475, 101 N.W. 610 (1904).

150. The jury trial statute set out in the text at note 55 supra has its present counterpart in N.Y. Civ. Prac. ACr $\$ 425$ (1920). This represents a change in form from the original provision, but not in substance, so far as the present problem goes. Section 4101 of the New York Civil Practice Law and Rules which will take effect on September 1, 1963, however, will completely reverse the rule which is described in the text. The new section reads: "In the following actions, the issues of fact shall be tried by a jury ... exccpt that cquitable defenses and equitable counterclaims shall be tried by the court." (Ital. supplied). An enumeration follows which is reminiscent of, but not exactly like, that in the present Section 425 , but adds " 3 . Any other action in which a party is entitled by the constitution or by express provision of law to a trial by jury." N.Y. Crv. PrAC. L. R. § 4101 (1962).

151. See text at note 55 supra. This and the following sentences in the text attempt to describe the reasoning in Susquehanna S.S. Co. v. A. O. Andersen \& Co., 239 N.Y. 285, 146 N.E. 381 (1925).

152. N.Y. Crv. PrAc. Acr $\S(1920)$. This section is omitted from N.Y. Crv. PrAc. L. R, (1962) which will take effect on September 1, 1963. See also note 150 supra.

153. N.Y. Crv. PRAC. ACT \& 424 (1920). 
mode of trial of a counterclaim is to be determined by the nature of the counterclaim itself, not that of the action in which it is interposed. Since, as we have seen, equitable matter was formerly presented by an independent suit, there is historical justification for treating any such matter as a counterclaim. ${ }^{164}$ And since the equitable matter usually has no greater substantive effect than to defeat the law action, there is analytical justification for treating nearly all such matter as a defense. ${ }^{165}$ New York apparently chose the analytical test; equitable matter constitutes a counterclaim only in the relatively rare case where defendant needs something more for his complete protection than a simple judgment in his favor (e.g., an injunction against plaintiff's transfer of a negotiable instrument). In most juridictions the matter of jury trial is not governed by any distinction between defense and counterclaim but upon the historical question whether defendant would have had to resort to equity in order to defeat the legal claim.168

(3) a question whether an order that equitable issues be tried first is appealable under section 1292 of the federal Judicial Code ${ }^{157}$ as an order granting an injunction. ${ }^{168}$ The historical basis for regarding it as such is clear enough, but it is doubtful whether the reasons for making interlocutory orders dealing with injunctions immediately appealable (as an exception to the final judgment rule) have any application to a court's disposing of the order of judicial business before it.

4. Civil action wherein complaint presents equitable issues and counferclain presents legal issues

\section{a. Historical patterns}

Where A's equitable claim against B had no factual connection with B's legal claim against $A$, then each claim would require a separate action with its own mode of trial. ${ }^{159}$ Where there is a factual connection between the two claims so that they present one or more common issues of fact the problem was more complicated. There were at least two situations where this might have been the case.

In one situation, the equity plaintiff A sought what we may call actual or substantial equitable relief such as foreclosure of a mortgage, specific performance of a contract, an injunction against conduct (other than prosecuting a law suit) or the like. In the other type, A sought relief which, though in personam

154. Hinton, supra note 139.

155. Cook, supra note 139.

156. See note 147 supra.

157. 28 U.S.C. $\$ 1292$ (a) (1) (1958).

158. See Enelow v. N.Y. Life Ins. Co., 293 U.S. 379 (1935) (decided before merger) (indicated appealable); Ettelson v. Metropolitan Life Ins. Co., 317 U.S. 188 (1942) (held appealable) ; City of Morgantown v. Royal Ins. Co., 337 U.S. 254 (1949) (held not appealable) ; Moore, Conrarentary on tHe U.S. Judrctat. Code $492-94$ (1949).

159. Unless defendant sought to use his damage claim as a set-off against plaintifi's equitable claim, according to the principles formerly prevailing in equity. See Savings Bank of New London v. Santaniello, 130 Conn. 206, 33 A.2d 126 (1943). 
and coercive in form, was in effect a declaration of rights which would dispose of a potential legal claim by $B$ against $A$ on grounds which would have been available at law to defeat B's claim if B pursued it by legal action. In stich a case $A$ was a putative defendant at law, and he sought in equity simply to defeat the law action on grounds cognizable at law. Equity jurisdiction was sometimes based on the fact that A's defense (or some other right or interest of A) might be prejudiced by delay in the commencement of B's legal actioneither because that action was premature or because $B$ was free to delay it for tactical reasons. ${ }^{160}$ Equity jurisdiction was sometimes based on the desire to prevent a multiplicity of legal actions. ${ }^{161}$

In either type of situation described in the previous paragraph, B might have a legal claim against $A$ arising out of the same operative facts (indeed in the second type $B$ would always have such claim). In the first type of situation $B$ would have a choice whether to interpose his claim in the equity suit or to. save it for a separate action at law. The latter choice might entail defeat in the equity suit, but if B was willing to pay that price he could have jury trial of the legal issues presented by his own claim. ${ }^{162}$ Suppose, for example, that $A$, a contractor, sought to foreclose a mechanics' lien for the amount he claimed due for the installation of a heating plant for $B$, owner of the building. If $B$ had a claim for breach of contract because of defective installation of the plant (including, perhaps, consequential damages in excess of the amount claimed by A), B could use his claim to defeat or diminish the amount for which foreclosure was sought (in which case the issues concerning A's performance would be tried to the court alone). Or $B$ could fail in the equity suit to controvert $A$ 's performance, suffer foreclosure for the amount claimed by $A$ and then sue $A$ at law for damages for breach of contract. His former pleading (failure to deny A's performance) would be admissible against him as an admission, ${ }^{103}$ but the former decree would not preclude him from taking a new position and explaining to the jury why he had done so. It would not be res

160. American Life Ins. Co. v. Stewart, 300 U.S. 203 (1937), presents a typical situa* tion. Here a life insurance policy would become incontestable, by its terms, "two years from its date of issue," except for non-payment of premium. The insured had died but the beneficiary was in a position to postpone her suit until after the policy had become incontestable. The insurance company, claiming fraud by the insured in the application for the policy, sued for cancellation of the policy before it became incontestable. The court cited many federal and state decisions sustaining equitable relief in similar situations. See also Enclow v. N.Y. Life Ins. Co., 293 U.S. 379, 384 (1935) ; Prudential Ins. Co. v. Saxe, 134 F.2d 16, 32 (D.C. Cir. 1943).

161. See, e.g., Town of Fairfield v. Southport Nat. Bank, 77 Conn. 423, 59 A. 513 (1904) ; 1 Pomeroy, Equity Jurisprudence Sec. IV, particularly \$§ 261 h et seq. 264 a, 264 b, 269 (5th ed. 1941).

162. American Mills Co. v. American Surety Co., 260 U.S. 360 (1922); Reichert $v_{4}$ Krass, 13 Ind. App. 348, 40 N.E. 706, 41 N.E. 835 (1895) ; Johnson Service Co. v. Kruse, 121 Minn. 28, 140 N.W. 118 (1913); First Nat. Bank of Miles City v. Erling Bros., 61 S.D. 364, 249 N.W. 681 (1933).

163. 4 WigḾRE, EVIDENCE § 1067 (3d ed. 1940). 
judicata or collateral estoppel and it would not preclude B from later resort to law. ${ }^{164}$

In the second situation described, where $A$ sought equitable relief principally to defeat a contemplated law action by $B$; equity would sometimes enjoin the bringing or prosecution of a law action subsequently brought by $B$; sometimes it would not. This would depend upon all the circumstances and would rest to a considerable extent in the discretion of the chancellor. An example would be a suit by an insurer to cancel an insurance policy for fraud in the application, where the policy by its terms was to become incontestible on this ground after two years of its issuance, where the insured had died within the two years, and where the beneficiary would have had a longer time for bringing suit than the period of contestibility, and he had not yet brought suit. Fraud would be a defense to a legal claim brought within the contestible period, and so an issue triable to the jury. But the insurer needs protection against the possibility of delay by the beneficiary beyond that time-hence its resort to equity. Suppose now that after the equity suit was brought and still within the contestible period the beneficiary did bring his legal action. The way was then clear for the insurer to make its defense of fraud at law. But the beneficiary could still defeat this defense by withdrawing his law action (which he could do without prejudice) and bringing it again after the policy had become incontestible.

When faced with this later, but still timely, suit by the beneficiary, equity did not dismiss the insurer's suit (since there had been ground for equitable relief when it was brought). Rather, it did one of two things: it either retained the case on its docket until the insurer's defense was actually tried by jury in the law action, or it enjoined the prosecution of the law action and proceeded to try the fraud issue itself. The matter was said to rest within the jurisdiction of the trial court ${ }^{165}$ and the Supreme Court enumerated the following factors as appropriate guides for the exercise of such discretion:

There would be many circumstances to be weighed, as, for instance, the condition of the court calendar, whether the insurer had been precipitate or its adversaries dilatory, as well as other factors. In the end, benefit and hardship would have to be set off, the one against the other, and a balance ascertained. ${ }^{108}$

This situation, which involves an issue which was traditionally cognizable in either law or equity, is to be sharply distinguished from what we have described above as Pattern I and its variants, wherein the threshold issue is by tradition of exclusively equitable cognizance.

164. Restatedent, Judgarents $§ 68$ (2) and comments d, a, $f$ (1942); cf. Scott, Collateral Estoppel by Judgment, 56 HARv. L. Rev. 1 (1942), James, Consent Judgments as Collateral Estoppel 108 U. PA. L. Rev. 173 (1959).

165. American Life Ins. Co. v. Stewart, 300 U.S. 203 (1937); Phoenix Afut. L. Ins. Co. v. Conway, 11 N.Y.2d 367, 183 N.E.2d 754 (1962); cf. Prudential Ins. Co. v. Save, 134 F.2d 16 (D.C. Cir. 1943).

166. American Life Ins. Co. v. Stewart, supra note 165 , at 216. 


\section{b. Modern patterns}

It was widely stated under the Codes that the interposition of a legal counterclaim in an equitable action constituted a waiver by defendant of any right to jury trial he might otherwise have on the issues tendered by the counterclaim. ${ }^{167}$ Any such rule-which pits one objective of a merged procedure (economy of litigation) against another (preservation of jury trial) -is unfortunate. And where the counterclaim is compulsory, a rule which attaches the consequence of waiver to its interposition would probably be unconstitutional. ${ }^{168}$ Under later provisions for merger, like those of the Federal Rules, it is clear that the filing of a counterclaim-whether permissive or compulsory - does not constitute a waiver of jury trial. ${ }^{109} \mathrm{We}$ have also seen that (for different reasons) it is not a waiver under the New York Civil Practice Act.

If there is no waiver in this situation, the question comes down largely to one of whether the common issue is to be tried by the court or the jury. Where there is no factual connection between the claims, no problem arises since there is no common issue and each set of separate issues will be tried in the way appropriate to it, just as was the case before merger.

Where there is such a connection and a common issue, B's legal claim will usually be a compulsory counterclaim under the Federal Rules and their state counterparts. ${ }^{170}$ Where A seeks what we have called actual or substantial equitable relief, B can no longer preserve his legal claim for a jury by saving it out of the equity suit. The provision for compulsory counterclaim prevents that. ${ }^{171}$ This fact should not, however, deprive $B$ of his jury right. The best solution, and the simplest, would be to let him exercise his option today by simply claiming jury trial in the way provided by statute or rule. This treatment would parallel that accorded $A$ when he must join legal and equitable claims in the same complaint. ${ }^{172}$ Perhaps the suggested rule gives $\mathrm{B}$ a wind. fall here by letting him have a jury at a price which was less than the older system exacted. But no one gained from the payment of that price (double

167. James, Trial by Jury and the New Federal Rules of Procedure, 45 YALE L.J. 1022, 1033 (1936) ; Annot. 89 A.L.R. 1391 (1934).

168. See Bendix Aviation Corp. v. Glass, 81 F. Supp. 645, 646 (E.D. Pa. 1948) (since rules now make defendant's counterclaim in this case compulsory, "there can be no question of this defendant's having waived jury trial by putting in his claim as a counterclaim to an equitable action.").

169. Beacon Theatres v. Westover, 359 U.S. 500 (1959) ; Thermo-Stitch, Inc. v. ChemiCord Proc. Co., 294 F.2d 486 (5th Cir. 1961); Black v. Boyd, 248 F.2d 156 (6th Cir. 1957).

170. FED. R. Crv. Proc. 13(a) which provides in part:

A pleading shall state as a counterclaim any claim which at the time of serving the pleading the pleader has against any opposing party, if it arises out of the transaction or occurrence that is the subject matter of the opposing party's claims . . . .

The quoted rule is subject to certain conditions and an exception which need not be gone into here.

171. Wright, Estoppel by Rule: The Compulsory Counterclaim under Modern Pleading, 38 MINN. L. REv. 423 (1954).

172. See text accompanying notes $118-143$ supra. 
litigation) and the only possible benefit from requiring it was its tendency to restrict jury trials-which would not uniformly be regarded as a benefit.

Where A seeks equitable relief principally to defeat an action at law by B against him on grounds cognizable as a defense at law, and where $B$ interposes the law action by way of counterclaim, fidelity to the historical pattern would usually require that the order of trial sequence be left to the trial court's discretion, to be guided by the kind of factors enumerated in American Life Insurance Co. $v$. Stewart. ${ }^{173}$ This, it should be noted, is the only type of situation in which history warrants the use of discretion for this purpose. ${ }^{174}$ There is judicial authority for its use here under the merged procedure, but for the federal courts this authority was overruled by Beacon Theatres $\%$. Westover. ${ }^{175}$

\section{Civil action for declaratory judgment}

We have seen that equity would sometimes grant relief which had as its principal substantive effect the binding declaration of the rights of parties. ${ }^{170}$ But there were many situations in which equity would not grant such relief. The putative defendant in an action for breach of contract or for negligently causing personal injuries, who claimed to have a good defense to it, could not get equity to determine the validity of the defense. The remedy of interposing this defense to the law action, if and when brought, was thought adequate. ${ }^{177}$

Beginning with the 1920's a good many statutes were passed which provided broadly for actions seeking declaratory judgments with or without coercive relief in all types of situations, including those in which equity had given relief and those in which it had not, and including those in which plaintiff sought simply to establish his nonliability under a claim against him as well as those in which he sought some affirmative relief. ${ }^{178}$

The framers of declaratory judgment acts, like the framers of merged systems of procedure, took a neutralist position toward jury trial, seeking

173. 300 U.S. 203, 216 (1937). These are set forth in the text at note 166 supro.

174. See text accompanying notes 79-90 \& 165-166 sipra.

175. 359 U.S. 500 (1959).

176. See text at notes 160, 161 and 165 supra. Other examples may be found in Borchard, Dectaratory Judgenents Part I, Ch. IV (2d ed. 1941) (including equitable actions for removal of cloud from title, to impress a trust upon the legal title, to construe wills and other instruments, for interpleader, and so on).

177. See text accompanying notes 31 \& 146 sipra.

178. The Uniform Declaratory Judgment Act was approved by the National Conference of Commissioners on Uniform State Laws, and the American Bar Association in 1922, 9A U.L.A. 2 (1957). It has by now been adopted by 36 states, Puerto Rico and the Virgin Islands. 9 U.L.A. Cux. ANn. Pocket PART 9 (1962).

There is also a federal Declaratory Judgments Act, 28 U.S.C. $\$ \S 2201,2202$ (1958), and one in Connecticut and in New York. Conn. Gen. Stat. § 52-29 (1958); N.Y. Crv. Prac. Acr $\& 473$ (1943) ; N.Y. Crv. Prac. L. R. § 3001 (1962).

See Borchard, Declaratory Judgasents 1039 (Appendix) (2nd ed. 1941) setting forth some of the statutes, and some of the legislative history of the federal act. 
neither to contract nor to expand it. ${ }^{179}$ The courts worked out an essentially simple test for jury trial, quite consistent with this legislative intent. Where the declaratory judgment action did not fit into one of the existing patterns for equitable relief, but was, so to speak, an inverted law suit, then the parties had a right to jury trial. ${ }^{180}$ Where the declaratory judgment was the counterpart of a suit in equity, there was no such right. ${ }^{181}$ This simple and consistent pattern has been disrupted, for the federal courts, by the decision in Beacon Theatres v. Westover. 182

In this action Fox, operator of a movie theatre in San Bernardino, California, sued Beacon, operator of a drive-in theatre 11 miles from San Bernardino, seeking a declaration that Fox was not liable to Beacon for treble dannages under the antitrust laws and an injunction pendente lite to prevent Beacon from suing Fox and its distributors under these acts. The controversy arose over first-run clearances. Fox alleged that it had long been operating uncler contracts with distributors granting it exclusive rights to show first-run pictures in the "San Bernardino competitive area"; that when Beacon built its drive-in it notified Fox that it considered these contracts to be violations of the antitrust laws and threatened treble damage suits thereunder; that these notices and threats against Fox and its distributors gave rise to "duress and coercion" which deprived Fox of its valuable property right to negotiate these contracts. Threat of irreparable harm was charged.

179. See BoRCEARD, op. cit. supra note 178, at 399-404. That author had a larger part in promoting and drafting these statutes than any other individual. See United States F. \& G. Co. v. Koch, 102 F.2d 288, 290 (3d Cir. 1939), referring to Borchard as the "father" of the declaratory judgment in the United States. Borchard states:

It may be said that the draftsmen of the Uniform Act included the provision [Section 9] with the sole purpose of reporting any constitutional doubt on the point; it was not intended to indicate that the declaratory action is either equitable or legal or to indicate that jury trial, though demandable in common law cases, is necessary in any case. Declaratory relief is neither strictly equitable nor legal, although ... its historical sources are almost exclusively equitable.

BORCHARD, op. cit. stipra note 178, at 399.

Section 9 of the Uniform Act reads:

When a proceeding under this Act involves the determination of an issue of fact, stuch issue may be tried and determined in the same manner as issues of fact are tried and de. termined in other civil actions in the court in which the proceeding is pending.

9A U.L.A. § 9, at 210 (1957). See also FEd. R. Crv. P. 57.

180. Hargrove v. American Cent. Ins. Co., 125 F.2d 225 (10th Cir. 1942) ; Johnson v. Fidelity \& Cas. Co., 238 F.2d 322 (8th Cir. 1956) ; Pittman v. West Am. Ins. Co., 299 F.2d 405 (8th Cir. 1962); Baumgartner v. Schey, 143 Colo. 373, 353 P.2d 375 (1960). Sec also Aetna Cas. Co. v. Quarles, 92 F.2d 321, 325 (4th Cir. 1937); American Lumbermens Mut. Cas. Co., v. Timms \& Howard, Inc., 108 F.2d 497, 499-500 (2d Cir. 1939); Annot., 13 A.L.R.2d 777 (1950).

181. Beaunit Mills, Inc. v. Eday Fabric Sales Corp., 124 F.2d 563 (2d Cir, 1942); Linahan v. Linahan, 131 Conn. 307, 39 A.2d 895 (1944) ; Hornof v. Klee, 259 Minn. 139, 106 N.W.2d 448 (1960).

The cases cited in note 180 supra all recognize this either expressly or by implication.

Cases are collected in Annot., 13 A.L.R.2d 777 (1950).

182. 359 U.S. 500 (1959). 
Beacon answered and counterclaimed for treble damages. A common issue of the complaint and counterclaim was the reasonableness of the clearances granted to Fox, which depended, in part, on the existence of competition between the two theatres. Beacon made timely demand for jury trial of all the issues. The trial court, however, viewed the complaint as essentially equitable and ordered the issues tendered by it (including the common issue) to be tried by the court before jury trial of the issues tendered by the counterclaim. The Court of Appeals refused to interfere with this ruling. ${ }^{183}$ It recognized that the determination of the issue of clearances by the court would "operate either by way of res judicata or collateral estoppel so as to conclude both parties with respect thereto at the subsequent trial of the treble damage claim."184 But it concluded that since the issues tendered by the complaint were equitable they would have warranted a chancellor in exercising his discretion to enjoin prosecution of the later law action and that the trial judge under the merged system had a similar discretion in ordering trial sequence. ${ }^{185}$

The Supreme Court reversed. The holding itself is not radical. Fox may have been simply trying to circumvent Beacon's jury right by "jumping the gun" with an equitable action; the district court's exercise of discretion may have been so questionable as to border on abuse. ${ }^{180}$ But on the assumptions which the Court made (existence of a common issue and of grounds for equitable relief) ${ }^{\mathbf{1 8 7}}$ the decision represented an extension of defendants' jury trial right. Traditionally this had depended (in this context) upon the chancellor's discretion ; 188 now it is made a matter of right upon issues tendered both by an equitable claim and by a legal counterclaim.

Even this departure from the historical pattern is not radical, but the grounds given for it are cloudy and ambiguous and susceptible of an interpretation which would go far to abolish the historical test altogether and extend jury trial over most of the former domain of equity. ${ }^{180}$

183. Beacon Theatres, Inc. v. Westover, 252 F.2d 864 (9th Cir. 1958).

184." Id. at 874 .

185. Id. at 876 .

186. Cf. Prudential Insurance Co. v. Saxe, 134 F.2d 16, $31-33$ (D.C. Cir.), sert. denicd, 319 U.S. 745 (1943).

187. 359 U.S. at 503-04, 506.

188. See notes $165 \& 166$ supra and accompanying text.

189. Further cloudy and ambiguous reasoning is added by the Court's later opinion in Dairy Queen, Inc. v. Wood, 369 U.S. 469 (1962). Here again the actual decision is not radical, though, again, is points to something of an extension of jury trial right. The action was brought by owners of the trademark Dairy Queen against licensees of the trademark, for alleged breaches of the licensing contract by (1) failure to make the payments it called for, and by (2) continuing to use the trademark and collect money for that use after its right to do so had terminated by the first breach. The complaint sought a declaration that the contract was null and void, an accounting of profits illegally obtained since the first breach, and a permanent injunction restraining defendant from using the trademarls within the area of the exclusive license and from executing sub-licensing agreements to others which would thus infringe plaintiff's rights. McCullough v. Dairy Queen, Inc, $194 \mathrm{~F}$. Supp. 686, 687 (E.D. Pa. 1961). Defendants admitted the contract and claimed that there had 
For one thing, the Court argues, injunction against defendant's lawsuit is not needed for plaintiff's full protection under the merged procedure; and the remedies open to plaintiff under the Federal Rules make his remedy at law adequate, thereby undercutting his need for equitable relief. ${ }^{100}$ This of course is true in a sense, not only here but in a fairly wide class of cases wherein the main thrust of the equity suit was to defeat a potential legal claim on grounds cogniz-

been a novation under which there was no breach. Defendant also claimed that plaintiffs, because of violations of the antitrust laws, had come into court with unclean hands. Ibid.

The District Court regarded the complaint as one claiming equitable relief and struck defendant's demand for jury. Id. at 687-88.

Defendant, licensee, then sought mandamus to compel the district judge to vacate this order. The Court of Appeals denied this request without opinion, but the Supreme Court reversed this judgment and indicated that the writ should issue. 369 U.S. at 479-80.

The Court held that insofar as the complaint requests a money judgment it presents a claim which is unquestionably legal." Id. at 476. And since "the factual issues related to the question of whether there has been a breach of contract," are presented by this legal claim as well by the claims for equitable relief "the legal claims involved in the action must be determined prior to any final court determination of respondents' equitable claims." Id. at 479.

The reasoning of the majority opinion delivered by Mr. Justice Black, purported to rest on history, but it ignored half the historical picture. Reliance was placed on two cases decided under the former procedure in which the Supreme Court had upheld the right to jury trial of the issue of debt vel non where unsecured contract creditors sought equitable aid in collecting their claims. Scott v. Neely, 140 U.S. 106 (1891) ; Cates v. Allen, 149 U.S. 451 (1893). These decisions were said to scotch the notion that legal issues may be tried without a jury because they are "incidental" to equitable issues. 369 U.S. at 470-71. This notion, it was suggested, was a latter-day gloss, introduced by courts which had lost their waty in the merged procedure created by the federal rules.

The Court concludes from this its reaffirmation of the broad principle in Beccon "that where both legal and equitable issues are presented in a single case, 'only under the most imperative circumstances ... can the right to a jury trial of legal issues be lost through prior determination of equitable claims.' "Id. at 472-73.

What the Court fails-or refuses-to see is that the Scott and Catcs cases represent only one of the patterns followed by equity-the one we have called pattern II-and what is said is true, historically, only of that pattern. In other situations (probably including that in both Beacon and Dairy $Q$ ueen) equity would frequently have tried without a jury the very kinds of legal issues which were presented in those cases. See, e.g., Marsh v. Seymour, 97 U.S. 348 (1878) ; Liberty Oil Co. v. Condon Nat. Bank, 260 U.S. 235 (1922) ; American Lifo Ins, Co. v. Stewart, 300 U.S. 203 (1937).

This departure from history seems to have been clearly grasped by Judge Wisdom in Thermo-Stitch, Inc. v. Chemi-Cord Proc. Corp., 294 F.2d 486, 491 (5th Cir. 1961), where he said : "It is therefore immaterial that the case at bar contains a stronger basis for cquitable relief than was present in Beacon Theatres. It would make no difference if the equitable cause clearly out-weighed the legal cause so that the basic issue of the case taken as a whole is equitable. As long as any legal cause is involved the jury right it creates controls. This is the teaching of Beacon Theatres, as we construe it." Cf. also Minnesota Mut. Life Ins. Co. v. Brodish, 200 F. Supp. 777, 778 n.2 (E.D. Pa. 1962).

The Court in Dairy Queen quoted Judge Wisdom's language with apparent approval. 369 U.S. at 473 n.8. The ambiguity in Dairy Queen's reasoning lies in the doubt whether the Court will continue to ignore the equitable half of history consistently and completely, or, if not, just where it will draw the new line.

190. 359 U.S. at 507-09. 
able at law. The Court mentions "such equitable remedies as Bills of Peace, $Q$ uia Timet and Injunction"191 in this connection. Interpleader (where the grounds of the adverse claimants' claims are legal) would be another example, reformation still another. In all such cases modern systems substitute direct procedures for the cumbersome and circuitous injunction against lawsuits. ${ }^{102}$ But these beneficial short cuts of the blended procedures have not generally been looked on as legal remedies in a sense which would disrupt the historical pattern of jury trial. Rather they have been regarded as aimed at improving judicial administration without disturbing the previous balance between jury and nonjury trial.

Even more disturbing is the Court's treatment of the Declaratory Judgment Act as. providing a legal remedy which "necessarily affects the scope of equity." 193 As we have seen, the remedy provided by this Act is available in a wide variety of situations covering nearly the while spectrum of what used to be law and equity. It would be a proper vehicle for tendering issues which have traditionally been exclusively equitable as well as issues, like those in Beacon Theatres, which might appear in either a legal or equitable context and were sometimes tried to a jury. A claim of mutual mistake, for an accounting between partners, for a trust accounting or for advice by a trustee, to name only a few examples, could all be presented by an action for declaratory judgment. ${ }^{194}$ Indeed it is hard to think of an equitable claim that might not be. To be sure, coercive relief would often be needed for complete protection, but the Court recognized this possibility also in Beacon Theatres and showed that it could be taken care of by a temporary injunction pending jury determination of the issues of fact and by permanent injunction thereafter, if that was needed. ${ }^{195}$ Presumably, then, the "legal remedy" would be inadequate only in a case where permanent equitable relief would be needed before a jury could determine factual issues-a rare case indeed.

It is true, as the Court implied, ${ }^{198}$ that the Declaratory Judgment Act was not intended to expand the scope of equity jurisdiction or diminish anyone's right to jury trial. But it is just as true, as the dissent points out and the majority opinion simply ignores, that the "Act merely provided a new statutory remedy, neither legal nor equitable, but available in the areas of both equity and law."197 And it is equally clear that the Act, like the systems of merger, was meant to preserve, not to expand, the right to jury trial.

191. Id. at 509 .

192. Or, where an injunction is actually needed it may always be granted on a temporary basis until the legal claim is determined by a jury. 359 U.S. at 508; cf. Dairy Queen, Inc. v. Wood, 369 U.S. 469,479 (1962).

193. 359 U.S. at 509.

194. The breadth of the remedy may be seen from Borchard, Declaratory JudgMENTS (1934).

195. 359 U.S. at 508,510 .

196. Id.at 504 .

197. Id. at 515 . 
Probably the majority of the Court did not mean that the declaratory judgment remedy had swallowed up all (or nearly all) the realm of equity and extended jury trial to all civil actions. The reasoning suggests this as a possibility, but probably it was meant to be confined to cases where declaratory relief is sought to forestall a law action $;^{198}$ and if that is the meaning, this part of the argument has no broader implications than that which reasons from the expansion of legal remedies by the Federal Rules.

Even if this narrow interpretation is to be put on Beacon Theatres, it stands for what has been described above as a flexible rather than static rendering of the constitutional test, for the Court makes it clear that the constitutional right to a jury attaches to those areas wrested from "the scope of equity" by "ex" pansion of adequate legal remedies provided by the Declaratory Judgment Act and the Federal Rules."100 The present Court, which heavily favors the jury trial, will no doubt use this flexibility always to expand jury trial. The precedent for flexibility once firmly set, however, may be used by some future court to curtail jury trial by expanding concepts associated with the former equity jurisdiction.

\section{CoNCLUSION}

The foregoing treatment proposes in effect a fairly close judicial adherence to the historical test in determining the right to jury trial in the modern civil action, with any flexibility confined rather strictly to developments which fall within patterns, already blocked out by history. But it is natural that many will be impatient with a test at once so conservative and timid, and also so difficult to apply (especially in a generation which has so little concern with legal history). It is therefore natural that competing notions should emerge. These should be examined.

(a) An eclectic test. No one has explicitly suggested re-examination of the whole matter with a view to determining what issues or types of issues are best fitted for court trial or jury trial. If all were tabula rasa, and some solon were trying to devise an ideal system for the administration of justice, he would probably approach the jury trial problems with just such an inquiry in mind. ${ }^{200}$ And it may well guide the future course of those charged with

198. The federal cases which have cited and relied on Beacon have gone no further than this to date. See, e.g., Pittman v. West American Ins. Co., 299 F.2d 405 (8th Cir. 1962); Thermo-Stitch, Inc. v. Chemi-Cord Proc. Co., 294 F.2d 486 (5th Cir. 1961); Minnesota Mut. Life Ins. Co. v. Brodish, 200 F. Supp. 777 (E.D. Pa. 1962); Mitchell v. Michigan-U.S. Ind. G. \& L. Co., 189 F. Supp. 411 (E.D. Mich. 1960) ; Payne Land \& Livestock Co. v. Archulcta, 180 F. Supp. 651 (D. N.M. 1960) ; Inland Steel Prod. Co. v. MPH Mfg. Co., 25 F.R.D. 238 (N.D. III. 1959).

199. 359 U.S. at 509. After pointing out how the remedies provided by the Federal Rules and the Declaratory Judgment Act necessarily affect the scope of equity and call for reconsideration of the availability of equitable remedies, the Court continues: "This is not only in accord with the spirit of the Rules and the Act but is required by the provision in the Rules that ' $[t]$ he right to trial by jury as declared by the Seventh Amendment to the Constitution [. . .] of the United States shall be preserved . . . inviolate.'" Id. at 509-10.

200. Cf. Note, The Right to a Nonjury Trial, 74 HARv. L. REv. 1176, 1190 (1961). 
amending or recasting constitutions or, within narrower compass, of legislators. But as a guide for judicial, as opposed to political, action in the matter any such test meets serious difficulties. For one thing the constitutions themselves, as we have seen, impose a different test (namely an historical test which was never guided, even in the making, by the consideration here suggested as ideal). Furthermore, even if the matter is left to the people acting through their legislators, they lack any scientific way of telling what issues are best suited for jury or for court trial, ${ }^{201}$ and there is no general agreement (among judges, among politicians, within the profession, or in the community at large) about the matter or even about the underlying premises that should be assumed in making the evaluation. ${ }^{202}$ These difficulties seem to this writer quite insurmountable and indeed they should, it is submitted, inhibit judges from feeling free to take the bit in their teeth..$^{203}$ Nevertheless it is natural and inevitable that a court's own value judgments will influence its decisions in close and doubtful cases.

(b) The basic nature of the issue test. This test has been proposed by Professor Moore and approved by a number of courts. ${ }^{202}$ The trouble with it is that it furnishes no guide for telling what the basic nature of an issue is. There are some issues, to be sure, that would usually (perhaps always) arise

201. The studies made by Kalven, Zeisel, and others at Chicago bid fair to making a serious and worth-while contribution to this knowledge but the reports of them to date are incomplete. See, e.g., Kalven, The Jury, the Law, and the Personal Injury Damage Autard, 19 Onto St. L.J. 158 (1958), Zeiser, Kalven and Bucholz, Denay in taz Counts, Preface (1959).

202. This is a matter on which opinions have been deeply divided for a long time. Perhaps the most thoughtful recent attack on the jury's worth is to be found in Frank, Courts ON TRIAL (1949).

Contrast the favorable point of view expressed in the sources cited in James, Torl Latv in Midstream: Its Challenge to the Judicial Process, 8 Buffalo L. Rev. 315, 342-43 (1959).

The controversy continues to rage at many levels. See, e.g., Green, Juries and JusliceThe Jury's Role in Personal Injury Cases, 1962 U. ILI. L. F. 152; Hogan, Joseph Slory on Juries, 37 OR. L. Rev. 234 (1958) ; Flynn, Public Preference for the Jury, 22 N.Y. Sr. Bar Ass'N J. 103 (1960) ; Steinitz, A Condemnation of the Jury System and a Possible Alternative, 21 U. PITTS. L. REv. 52 (1959).

203. A wise and temperate judicial appraisal of the problem was made by Judge Clark, dissenting, in Damsky v. Zavatt, 289 F.2d 46, 59 (2d Cir. 1961) :

Of course American lawyers and judges have found the jury of immense value in assuming the burden of adjudicating troublesome issues of fact, notably in criminal and in negligence cases. But it is not showing care for the jury to force it into classes of claims where the right is dubious and the use inconvenient and burdensome. The present strain on juries in the cases where it is most needed is such that true believers should pause before they push it too far. The delays and court congestion of the jury calendars are a source of increasing tension, the long waits and infrequent sittings are a burden to the conscientious juror and lead him increasingly to avoid service, and Congress is regularly objecting to what it considers the undue cost of juries and cutting the appropriations therefor.

204. 5 MoOre, Federal Practice \ 38.16 (2d ed. 1951). Cases adopting this approach and citing Moore's treatise are cited in the footnotes to the second edition and in the current supplement. 
only in equity (e.g., mutual mistake as a basis for reformation; existence of facts which would warrant surcharge of an express trustee, etc.). Others would always, or nearly always, arise only at law (e.g., negligent operation of an automobile). Such issues may well enough be called basically equitable or legal, as the case may be. But they pose no serious problem as to mode of trial and no special test need be formulated for them. It is only when an issuc was cognizable in either law or equity, depending on the context, that problems are presented and a test needed. Such issues are not inherently legal or equitable. They are like chameleons which take their color from surrounding circumstances. When applied to such issues, the basic nature test has been called a subjective one, leaving the court free to find either way. ${ }^{206}$ But the test was probably not meant to leave matters thus at large and there are at least three ways in which it can be given objective content: (1) The basic nature of an issue could be defined in terms of the appropriate mode of trial for that issue. In this way the present test would be equated to the one just described as the eclectic test. This is clearly not what is meant. (2) An issue could be defined as basically legal whenever it is one that is regularly tried by a jury, though not uniformly. This would mean that an issue like fraud in the inducement, or contract vel non would be basically of a legal nature. This is not what the author of the test intended, ${ }^{200}$ though the notion could be justified on an assumption of the superiority of jury trial, at least wherever there was some basis of experience with it upon an issue. If fraud, for instance, had long been tried to a jury in some cases, this must indicate that it is a practical way to try this issue. Therefore, since its superiority as a mode of trial is assumed, it should be extended to the issue of fraud wherever it is raised. A variant of this notion would be to regard an issue as basically legal wherever it is a common issue tendered by both an equitable suit and a legal counterclaim. The assumption of the superiority of jury trials probably constitutes the basis of the Supreme Court's current position, though it is not formtlated in terms of "the basic nature of an issue." Indeed the majority opinion in Beacon Theatres rejects the basic nature test. (3) The basic nature of an issue could be defined in terms of its context in the light of history. This would equate it with the historical test. This is apparently what Professor Moore means, as the illustrations he gives suggest. But if it is, then it adds nothing helpful or clarifying. Instead it adds confusion by suggesting either unbridled choice or irrelevant inquires and in either event it tempts an excursion down some primose path.

(c) The test of discretion. Trial courts have and should have some discretion in prescribing the order of the business before them. This is confirmed and extended for the federal courts by Rule 42 (b) which empowers a court to order separate trials of separate issues. Some courts have suggested that this

205. See Note, 47 CALIF. L. REv. 760, 762 (1959) ("The determination as to which is the basic issue appears arbitrary."); Note, 45 Iowa L. REv. 603, 606 (1960) ("The deter" mination would depend entirely upon the individual attempting to apply the test.").

206. Thus Professor Moore states that the basic nature of the issue in patent litigation will depend upon the patentee's choice of remedy, 5 MooRE op. cit. sitpra note 204, at 151, and that the choice of remedy as between damages and specific performance will govern the nature of such issues as contract vel non. Id. at 152. 
discretion provides the solution for the problems of jury trial where an issue is tendered which would be cognizable either at law or in equity and one party claims a jury. ${ }^{207}$ But discretion cannot determine whether a strict constitutional right is to be accorded. And since the constitution preserves the jury right as it existed historically, then discretion may constitutionally be employed to deny a jury trial only where a court of equity would have (or might have) enjoined an action at law under the old system. Moreover, unless merger is to be used as a cloak for extending jury trial in a way that the framers of merger did not contemplate, then discretion has no place in determining whether a common issue is to be tried to the jury, except where a court of equity would have exercised discretion in deciding whether to enjoin an action at law. This was the case in only one narrow type of situation, as we have seen; namely, where A brings an equity suit to establish what would be a good legal defense to B's potential law suit, and the ground of equitable jurisdiction was the avoidance of multiple actions or of hardship caused by the possible delay in bringing B's action. It was precisely in this situation that the Supreme Court virtually eliminated the availability of judicial discretion to determine whether a common issue shall be tried by jury. This ruling does not, of course, bind state courts. ${ }^{208}$ Nor would it prevent a federal court from exercising discretion in determining the order in which court and jury issues are to be tried in many cases (as where these are all different issues). But apparently there is little or no room for discretion in the federal courts to decide whether any given issue is to be tried by a jury by the device of controlling trial sequence.

207. See, e.g., Tanimura v. United States, 195 F.2d 329 (9th Cir. 1952); Orenstein v. United States, 191 F.2d 184, 190 (1st Cir. 1951).

208. So far Beacon has created scarcely a ripple in the state courts. It has been cited altogether less than a half dozen times. Srepards, U.S. Cirations 423 (Jan. 1963). And only three decisions in which it was cited have any significance for present purposes. In Temperance Ins. Exch. v. Carver, 83 Idaho 487, 493, 365 P. 2d 824, 827, 828 (1961), it was cited twice; once for the proposition: "... the trial of issues of fact incidental to the exercise of rights and remedies granted by the declaratory judgment act, are generally triable before the court without a jury"; the second time for the proposition: "However, when issues of fact triable by jury under the common law or territorial statute, arise in declaratory proceedings, the procedure must be such as to preserve the right of jury trial."

In Pheonix Mut. L. Ins. Co. v. Conway, 11 N.Y. 2d 367, 371, 183 N.E. $2 d 754,756$ (1962), the court, after sustaining an order for court trial first as a proper exercise of discretion in a situation like that in the Stewart case, note 189 sipra, cites Sicurart as authority, and concludes " $C f$. Beacon Theatres, Inc. v. Westover...."

In Romero v. King, 368 Mich. 45, 55, 117 N.W. 2d 119, 124 (1962), it was cited in Arr. Justice Black's opinion for one-half of a divided court, for the proposition that Dairy Queen and Beacon called for a "scrutinous reexamination" of the decision in Style v. Greenslade, 364 Mich. 679, 112 N.W. 2d 92 (1961). Style reaffirmed a Michigan rule (seldom found elsewhere) that a challenge to a release of a claim for personal injuries, on grounds of fraud and overreaching, presented an equitable issue for determination by the court alone. The Michigan Court has recently adopted rules modeled on the federal rules. The justices who agreed with $\mathrm{Mr}$. Justice Black apparently believe that this step, coupled with the recent Supreme Court opinions, calls for repudiation of the peculiar Alichigan rule found in Style, and its replacement by the widely prevailing rule that a defense or avoidance grounded on fraud is triable to the jury when presented in the context of a common law action. Sce Bowie v. Sorrell, 209 F.2d 49 (4th Cir. 1953); Annot, 43 A.L.R.2d 786 (1955). Compare note 31 supra. 